\title{
Mercury emissions of a coal-fired power plant in Germany
}

\author{
Andreas Weigelt ${ }^{1, a}$, Franz Slemr ${ }^{2}$, Ralf Ebinghaus ${ }^{1}$, Nicola Pirrone ${ }^{3}$, Johannes Bieser ${ }^{1,4}$, Jan Bödewadt ${ }^{1}$, \\ Giulio Esposito $^{3}$, and Peter F. J. van Velthoven ${ }^{5}$ \\ ${ }^{1}$ Helmholtz-Zentrum Geesthacht (HZG), Institute of Coastal Research, Geesthacht, Germany \\ ${ }^{2}$ Max-Planck-Institute for Chemistry (MPI-C), Department of Atmospheric Chemistry, Mainz, Germany \\ ${ }^{3}$ National Research Council (CNR), Institute of Atmospheric Pollution Research, Rende, Italy \\ ${ }^{4}$ Deutsches Zentrum für Luft- und Raumfahrt (DLR), Institute of Atmospheric Physics, Oberpfaffenhofen, Germany \\ ${ }^{5}$ Royal Netherlands Meteorological Institute (KNMI), Chemistry and Climate Division, De Bilt, the Netherlands \\ ${ }^{a}$ now at: Federal Maritime and Hydrographic Agency (BSH), Hamburg, Germany
}

Correspondence to: Andreas Weigelt (andreas.weigelt@bsh.de) and Franz Slemr (franz.slemr@mpic.de)

Received: 4 May 2016 - Published in Atmos. Chem. Phys. Discuss.: 22 June 2016

Revised: 5 October 2016 - Accepted: 6 October 2016 - Published: 3 November 2016

\begin{abstract}
Hg} / \mathrm{SO}_{2}, \mathrm{Hg} / \mathrm{CO}, \mathrm{NO}_{x} / \mathrm{SO}_{2}\left(\mathrm{NO}_{x}\right.$ being the sum of $\mathrm{NO}$ and $\mathrm{NO}_{2}$ ) emission ratios (ERs) in the plume of the coal-fired power plant (CFPP), Lippendorf, near Leipzig, Germany, were determined within the European Tropospheric Mercury Experiment (ETMEP) aircraft campaign in August 2013. The gaseous oxidized mercury (GOM) fraction of mercury emissions was also assessed. Measured $\mathrm{Hg} / \mathrm{SO}_{2}$ and $\mathrm{Hg}$ / CO ERs were within the measurement uncertainties consistent with the ratios calculated from annual emissions in 2013 reported by the CFPP operator, while the $\mathrm{NO}_{x} / \mathrm{SO}_{2}$ ER was somewhat lower. The GOM fraction of total mercury emissions, estimated using three independent methods, was below $\sim 25 \%$. This result is consistent with other findings and suggests that GOM fractions of 40\% of CFPP mercury emissions in current emission inventories are overestimated.
\end{abstract}

\section{Introduction}

Mercury and especially methyl mercury, which bioaccumulates in the aquatic nutritional chain, are harmful to humans and animals (e.g., Mergler et al., 2007; Scheuhammer et al., 2007; Selin, 2009; and references therein). Therefore, $\mathrm{Hg}$ emissions are on the priority list of several international agreements and conventions dealing with environmental protection and human health, including the United Nations Environment Program (UNEP) Minamata convention on mercury (www.mercuryconvention.org). Mercury is emitted to the atmosphere from a variety of natural (e.g., volcanic ac- tivity, evaporation from ocean and lakes) and anthropogenic sources (e.g., coal and oil combustion; Mason, 2009; Pirrone et al., 2010). Coal-fired power plants (CFPPs) are believed to account for most ( $\geq 56 \%$ ) of mercury emitted by stationary combustion sources, which constitute $35-77 \%$ of all anthropogenic Hg emissions (Pirrone et al., 2010; Chen et al., 2014; Ambrose et al., 2015).

Mercury from CFPPs is emitted as gaseous elemental mercury (GEM), gaseous oxidized mercury (GOM) and particulate bound mercury (PBM). Elemental mercury has a high vapor pressure and is virtually insoluble in water, resulting in a long residence time in the atmosphere of about $6-12$ months (Slemr et al., 1985; Lindberg et al., 2007; Selin, 2009; Holmes et al., 2010). GOM, with its high solubility and low vapor pressure, is readily washed and rained out, as are the particles carrying mercury (particle bond mercury). In addition, GOM is also rapidly removed by dry deposition. GOM and PBM are believed to be in equilibrium (Rutter and Schauer, 2007; Amos et al., 2012). GOM is thus a major driver for the global mercury deposition and is estimated to make up more than $50 \%$ of the total Hg deposition (Zhang et al., 2012a; Bieser et al., 2014).

There are only two sources of GOM in the atmosphere: primary GOM emissions from anthropogenic sources and the oxidation of elemental mercury. The major anthropogenic mercury sources on a global scale are small-scale artisanal gold mining (SSAG) and coal combustion (Pirrone et al., 2010). While SSAG emits solely elemental mercury, the CFPP emissions in emission inventories are estimated to 
have a GOM fraction between 35 and $40 \%$ (Pacyna et al., 2006; Wilson et al., 2010; EPA, 2011). However, global and regional model studies have repeatedly indicated that models are overestimating atmospheric GOM concentrations (Zhang et al., 2012b; Kos et al., 2013; Bieser et al., 2014). Possible explanations for this are an overestimation of the in-plume GEM oxidation rates or the overestimation of the amount of GOM emitted by CFPPs. The latter has been hypothesized to be due to a fast reduction of GOM inside the plume (Zhang et al., 2012b; Kos et al., 2013).

The speciation of CFPP emissions is not well known. That is because of varying composition of coal burned, complex chemistry in the stack gases (e.g., Lohman et al., 2006; Schofield, 2008; Tatum Ernest et al., 2014), and the large number of different methods used to clean CFPP flue gases, with very different percentages of GOM to total mercury, ranging from less than 10 up to $90 \%$ (Wang et al., 2010; Schütze et al., 2012, 2015, and references therein). Analytical problems also contribute to the uncertainty: the current emission monitoring systems are not sensitive enough to measure and speciate low mercury concentrations in flue gases of modern CFPPs (Mayer et al., 2014). Moreover, there has been evidence that the current ambient air measurement systems might not capture all oxidized mercury species with similar efficiency (Jaffe et al., 2014; Gustin et al., 2013, 2015; Weiss-Penzias et al., 2015).

The European Tropospheric Mercury Experiment (ETMEP) was carried out in July/August 2012 (ETMEP-1) and August 2013 (ETMEP-2) to measure local emissions, vertical profiles from inside the boundary layer to the lower free troposphere, and horizontal distribution of mercury over Europe. Altogether, 10 measurement flights were performed over Italy, Slovenia, and Germany with two propeller aircraft. The ETMEP-1 campaign focused on volcanic emissions of Mount Etna. The objectives of the ETMEP-2 campaign were (a) to obtain vertical mercury profiles above several sites in central and southern Europe (Weigelt et al., 2016), (b) to assess horizontal distribution of mercury concentrations during the flights between Italy and Germany, and (c) to determine mercury emission ratios for a CFPP near Leipzig. Here, we present the measurements of CFPP emissions and their speciation.

\section{Experimental}

The power plant under investigation is located in Lippendorf, a small village ca. $15 \mathrm{~km}$ south of Leipzig in Germany. The Lippendorf CFPP consists of two units with 934 MW gross power each. It has been in operation since 2000 and belongs, with a net efficiency of $42.6 \%$, to one of the most modern and efficient lignite-fueled power plants in Europe. About 750 metric tons per hour $\left(\mathrm{t} \mathrm{h}^{-1}\right)$ of lignite from a nearby open pit mine "Vereinigtes Schleenhain" are burnt together with $\sim 22 \mathrm{th}^{-1}$ of sewage sludge (Schütze et al.,
2015). Mercury content of lignite from two seams of "Vereinigtes Schleenhain" was 0.40 and 0.49 ppm (Rösler et al., 1977), within the range between 0.16 and $1.5 \mathrm{ppm}$ for eastern German lignites (Yudovich and Ketris, 2005). No data about mercury content of the sewage sludge are available. The flue gas is directed through an electrostatic filter and a flue gas desulfurization (FGD) system to reduce particle and $\mathrm{SO}_{2}$ emissions. The FGD uses wet washing with $\mathrm{CaO}$ suspension with added sulfidic precipitant and removes $\sim 80 \%$ of mercury (Schütze et al., 2015). Despite the efficient FGD cleaning, the Lippendorf CFPP ranks fourth most healthharmful emitter in Germany (rating based on combined emissions of $\mathrm{SO}_{2}, \mathrm{NO}_{x}$, and particulate matter; Preiss et al., 2013) and 14th most harmful emitter in Europe according to the European Environment Agency (rating based on combined emissions of $\mathrm{SO}_{2}, \mathrm{NO}_{x}, \mathrm{NH}_{3}, \mathrm{CO}_{2}$, particulate matter, nonmethane hydrocarbons, heavy metals, and organic micropollutants; EEA, 2011) with respect to health. Annual emissions reported by the operator of the Lippendorf CFPP for 2013 , the year of our measurements, were $1.18 \times 10^{13} \mathrm{~g} \mathrm{CO}_{2}$, $1.21 \times 10^{10} \mathrm{~g} \mathrm{SO}_{2}, 7.91 \times 10^{9} \mathrm{~g} \mathrm{NO}_{x}, 7.55 \times 10^{8} \mathrm{~g} \mathrm{CO}$, and $4.1 \times 10^{5} \mathrm{~g} \mathrm{Hg}$, among other pollutants. Mercury limit emission values (LEVs) of large combustion plants in Germany are stipulated by ordinance (Federal Law) from 2004 and its revision in 2013 to $50 \mu \mathrm{g} \mathrm{m}^{-3}$ as a half-hour average, $30 \mu \mathrm{g} \mathrm{m}^{-3}$ as a daily average, and $10 \mu \mathrm{g} \mathrm{m}^{-3}$ as an annual average concentration (Mayer et al., 2014). Continuous monitoring of mercury emissions is mandatory but only annual total (unspeciated) mercury emissions have to be reported. European Union (EU)-wide LEVs of $<5 \mu \mathrm{g} \mathrm{m}^{-3}$ for hard coal and $<7 \mu \mathrm{g} \mathrm{m}^{-3}$ for lignite-fired CFPPs are under discussion (VGB, 2016).

The measurement campaign described above was performed with a CASA 212 two-engine turboprop aircraft (Fig. 1a) operated by Compagnia Generale Ripreseaeree (http://www.terraitaly.it/). The CASA 212, with a maximum payload of $2.7 \mathrm{t}$, can carry the measurement instruments, different service instruments, the power supply, two pilots, and five operators. With a normal cruising speed of $\sim 260 \mathrm{~km} \mathrm{~h}^{-1}$, its range is $\sim 1600 \mathrm{~km}$. Although the maximum flight level of the unpressurized aircraft is $8500 \mathrm{~m}$, the maximum altitude of ETMEP-2 flights without oxygen supply was limited to $\sim 3000 \mathrm{~m}$ above sea level (a.s.l.),

The aircraft was equipped with a gas inlet system (Fig. 1b), which had been developed and manufactured at the Helmholtz-Zentrum Geesthacht. The gas inlet was designed for the cruising speed of the CASA 212 of $\sim 72 \mathrm{~m} \mathrm{~s}^{-1}$. A diffuser tube reduced the air speed to $\sim 5 \mathrm{~m} \mathrm{~s}^{-1}$. About $120 \mathrm{~L} \mathrm{~min}^{-1}$ (ambient conditions) enters the inlet. The air sample is taken in the center of the diffuser tube with a flow rate of $\sim 25 \mathrm{~L} \mathrm{~min}^{-1}$. The remaining flow of $95 \mathrm{~L} \mathrm{~min}^{-1}$ is directed to the back of the inlet, where the airspeed is increased by a nozzle and the air exits. By replacing the inlet and outlet nozzle with smaller or larger ones, this inlet system can be fitted to other aircraft with a different cruising speed. 

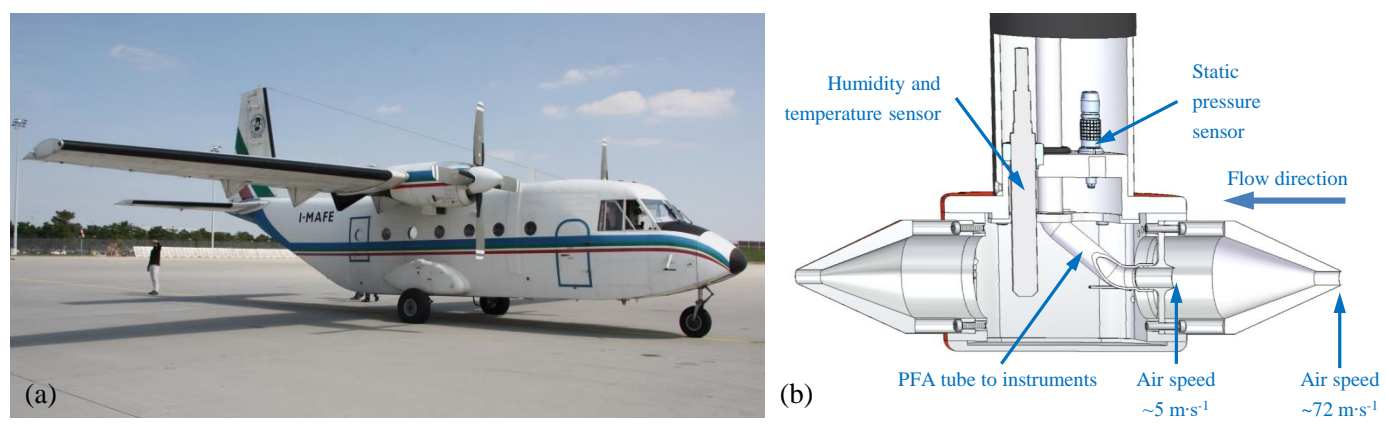

Figure 1. For the ETMEP-2 campaign in August 2013 the CASA 212 (a) from the Italian company, Compagnia Generale Ripreseaeree (http://www.terraitaly.it/), was equipped with specially designed and manufactured trace gas inlet (b).

In the expanded area (behind the main sample line) the air temperature $(T)$, static pressure $(p)$, and relative humidity $(\mathrm{rH})$ are measured. To avoid adsorption losses of sticky trace gases, the internal surface of the inlet system was coated with Teflon and only PFA tubing was used for the sampling lines. The outside of the inlet was coated with copper to avoid electrostatic charging. The inlet was fastened onto a $90 \mathrm{~cm}$ long telescope tube $(6 \mathrm{~cm}$ diameter), which was mounted in a hole on the floor fuselage via a sliding guide. After takeoff, the tube was pushed down by $\sim 40 \mathrm{~cm}$ from inside the aircraft, to ensure that the inlet nozzle was outside the aircraft boundary layer. Before landing the tube was pulled back into the aircraft to protect it from damage by objects whirled up by the front wheel. The inlet and the telescope tube were equipped with heaters to prevent icing, but during the ETMEP measurements the heating was always switched off because the measurement flights were carried out in summer at altitudes below $3000 \mathrm{~m}$ a.s.l. The tubing from the inlet to instruments ( $\sim 2.5 \mathrm{~m}$ long $3 / 8$ " O.D. main sample tube with PFA manifolds to instruments) was not heated. The temperature inside the cabin was 18 to $30^{\circ} \mathrm{C}$.

The aircraft was equipped with three mercury measurement instruments: a Lumex RA915AM, a Tekran 2537B, and a Tekran 2537X (cf. Table 1). The Lumex RA-915 AM is based on atomic absorption spectroscopy (AAS) with Zeeman background correction (Sholupov et al., 2004), and as such, measures specifically only gaseous elemental mercury (GEM) with a temporal resolution of $1 \mathrm{~s}$. Its raw signal is noisy (about $\pm 4 \mathrm{ng} \mathrm{m}^{-3}$ with a temporal resolution of $1 \mathrm{~s}$ ) and is dependent on pressure and temperature. Nevertheless, the fast response of the instrument is very useful to detect GEM in rather narrow, highly concentrated plumes at a cruising speed of about $72 \mathrm{~m} \mathrm{~s}^{-1}$. Because of thermal drifts, its zero was measured every 4 min for 1 min using an internal active-carbon zero-air cartridge.

The Tekran 2537B and 2537X analyzers are based on preconcentration of mercury and its compounds on gold traps (Slemr et al., 1979), thermal desorption, and detection by cold vapor atomic fluorescence spectroscopy (CVAFS). Although CVAFS can detect only GEM, mercury compounds are converted to GEM during adsorption or thermal desorption (Slemr et al., 1978) and, consequently, Tekran instruments can measure total gaseous mercury (TGM). The instruments use two gold traps to ensure a continuous measurement; while one is adsorbing mercury during sampling, the other one is being analyzed and vice versa. The highest temporal resolution of the Tekran instruments of $150 \mathrm{~s}$ is given by the time necessary for the thermal desorption of mercury from the gold traps and their cooling. The Tekran $2527 \mathrm{X}$ analyzer (Tekran 1) was run with a quartz wool trap upstream of the instrument, which removed gaseous oxidized mercury (GOM) and aerosol particles with particle bound mercury (PBM) but no GEM from the air stream (Lyman and Jaffe, 2012; Ambrose et al., 2013). The Tekran 2537B (Tekran 2) analyzer was operated as a backup instrument without a quartz wool trap. The Teflon-made (PFA and PTFE) aircraft gas inlet and tubing system are similar to the CARIBIC trace gas inlet for which high GOM transmission was qualitatively demonstrated. Based on the short residence time $(0.3 \mathrm{~s})$ in the tubing to the instrument, the conditions during an international field inter-comparison (Ebinghaus et al., 1999), and higher GOM concentrations in the plume than in ambient air, we presume Tekran measurements without a quartz wool trap represent total gaseous mercury $(\mathrm{TGM}=\mathrm{GEM}+\mathrm{GOM})$. Therefore, the Tekran 2537B measurements are believed to represent TGM concentrations whereas those by Tekran are believed to represent $2537 \mathrm{X}$ GEM concentrations, both with an uncertainty of $12.5 \%$. The uncertainty has been calculated by Weigelt et al. (2013) using two different approaches according to ISO 20988 type A6 and ISO 20988 Type A2. This uncertainty complies with the quality objective of the EU air quality directive 2004/107/EC. The instrumental setup in the aircraft was almost identical and, therefore, we expect the uncertainty to be similar.

Direct estimation of the GOM concentrations was made using three manual $\mathrm{KCl}$ denuder samples taken during the vertical profiles: one downwind of the Lippendorf CFPP, one upwind over the city of Leipzig (both on 21 August 2013), and one over the GMOS (Global Mercury Observa- 
Table 1. List of instruments in the CASA 212 research aircraft. GEM is gaseous elemental mercury and GOM is gaseous oxidized mercury.

\begin{tabular}{|c|c|c|c|c|}
\hline Parameter & Instrument name & Temporal resolution & Uncertainty & Lower detection limit \\
\hline GEM & $\begin{array}{l}\text { Lumex RA-915AM } \\
\text { (modified, } \\
\text { T-stabilized by } \\
\text { Lumex company) }\end{array}$ & $\begin{array}{l}1 \mathrm{sec}(\mathrm{raw} \\
\text { signal) }\end{array}$ & $\begin{array}{l} \pm 4 \mathrm{ng} \mathrm{m}^{-3} \\
\left(1 \mathrm{~s}^{-3} \text { aw signal) }\right. \\
\pm 1 \mathrm{ng} \mathrm{m}^{-3} \\
\text { (10 s average) }\end{array}$ & $\begin{array}{l}0.5 \mathrm{ng} \mathrm{m}^{-3} \\
(120 \mathrm{~s} \text { average })\end{array}$ \\
\hline GEM & $\begin{array}{l}\text { Tekran: } 2537 \mathrm{X} \\
\text { (with upstream } \\
\text { quartz wool trap) }\end{array}$ & $150 \mathrm{~s}$ & $\pm 12.5 \%$ of reading & $0.1 \mathrm{ng} \mathrm{m}^{-3}$ \\
\hline $\begin{array}{l}\text { GEM + unknown } \\
\text { amount of GOM }{ }^{1}\end{array}$ & Tekran 2537B & $150 \mathrm{~s}$ & $\pm 12.5 \%$ of reading & $0.1 \mathrm{ng} \mathrm{m}^{-3}$ \\
\hline GOM & $\begin{array}{l}\text { manual denuder } \\
\text { samples }\end{array}$ & $\begin{array}{l}2600 \text { to } \\
3600 \mathrm{~s}\end{array}$ & $\pm 5 \mathrm{pg} \mathrm{m}^{-3^{2}}$ & $1 \mathrm{pg} \mathrm{m}^{-3}$ \\
\hline $\mathrm{CO}$ & Aero Laser AL5002 & $1 \mathrm{~s}$ & $\pm 3 \%$ of reading & $1.5 \mathrm{ppb}$ \\
\hline $\mathrm{O}_{3}$ & Teledyne API 400E & $10 \mathrm{~s}$ & $\pm 2 \%$ of reading & $0.6 \mathrm{ppb}$ \\
\hline $\mathrm{SO}_{2}$ & Thermo: 43C Trace Level & $10 \mathrm{~s}$ & $\pm 4 \%$ of reading & $0.2 \mathrm{ppb}$ \\
\hline $\begin{array}{l}\mathrm{NO} \\
\mathrm{NO}_{2}\end{array}$ & Teledyne API M200AU & $\begin{array}{l}10 \mathrm{~s} \\
10 \mathrm{~s}\end{array}$ & $\pm 10 \%$ of reading & $0.05 \mathrm{ppb}$ \\
\hline Pressure & $\begin{array}{l}\text { Sensor Technics } \\
\text { CTE7001 }\end{array}$ & $1 \mathrm{~s}$ & $\pm 1 \%$ of reading & 0 mbar \\
\hline Temperature & $\begin{array}{l}\text { LKM Electronic } \\
\text { DTM5080 }\end{array}$ & $1 \mathrm{~s}$ & $\pm 0.13^{\circ} \mathrm{C}$ & $-50^{\circ} \mathrm{C}$ \\
\hline Relative Humidity (rH) & Vaisala HMT333 & $8 \mathrm{~s}$ & $\begin{array}{l} \pm 1.0 \% \mathrm{rH} \\
(0-90 \% \mathrm{rH}) \\
1.7 \% \mathrm{rH} \\
(90-100 \% \mathrm{rH})\end{array}$ & $0 \%$ \\
\hline $\begin{array}{l}\text { GPS data ( } 3 \text {-D position, } \\
\text { speed, heading) }\end{array}$ & POS AV & $1 \mathrm{~s}$ & $\begin{array}{l} \pm 5 \mathrm{~m} \text { (horizontal })^{3} \\
\pm 15{\text { (vertical })^{3}}^{3}\end{array}$ & - \\
\hline
\end{tabular}

${ }^{1}$ The aircraft inlet system transmission efficiency for GOM was not tested because no GOM sources were available for measurements during the flight. ${ }^{2}$ Difference of the two blank tests. ${ }^{3}$ The GPS accuracy is dependent on the number of satellites. The given numbers are estimated values.

tion System) master site "Waldhof" in northern Germany on 22 August (Fig. 2). For sampling, the $\mathrm{KCl}$ denuders were connected to a bypass of the main sampling line about $1.2 \mathrm{~m}$ downstream from the above-described Teflon-coated gas inlet. The sampling flow rate was controlled with a mass flow controller downstream from the $\mathrm{KCl}$ denuder and was set to $6.4 \mathrm{~L} \mathrm{~min}^{-1}$ at standard temperature and pressure (STP; $T=273.15 \mathrm{~K}, p=1013.25 \mathrm{hPa}$ ), corresponding to $\sim 10 \mathrm{Lmin}^{-1}$ at ambient temperature and pressure in $3000 \mathrm{~m}$ a.s.l. The sampling time was $1 \mathrm{~h}$ or longer, corresponding to a total sample volume of $600 \mathrm{~L}$ or more. The $\mathrm{KCl}$ denuder was kept at a constant temperature of $50^{\circ} \mathrm{C}$ using a heater band. Two blank samples were also taken using $\mathrm{KCl}$ denuders and handled exactly in the same way as the samples (denuder preparation, installation to sampling setup, storage, analysis) but without sucking sample air through them. Five days before the ETMEP-2 campaign started all denuders were prepared for sampling by being coated with $\mathrm{KCl}$ and purged at $500^{\circ} \mathrm{C}$ for $60 \mathrm{~min}$ in a Tekran 1130 speciation unit with mercury-free air from a Tekran active carbon zero air cartridge. During the heating, mercury in the flushing air downstream from the $\mathrm{KCl}$ denuders was measured with a Tekran 2537B mercury analyzer to ensure that mercury was quantitatively removed from the $\mathrm{KCl}$ denuders. After the campaign the $\mathrm{KCl}$ denuders were analyzed in the laboratory for their total GOM loads using the same setup as for the denuder preparation. The lower detection limit was estimated to be $1 \mathrm{pg} \mathrm{m}^{-3}$ and is dominated by the Tekran 2537 lower detection limit $\left(0.1 \mathrm{ng} \mathrm{m}^{-3}\right)$. The overall method uncertainty, defined as a difference of the two blanks, is relatively high with about $\pm 5 \mathrm{pg} \mathrm{m}^{-3}$. Nevertheless, the method provides semi-quantitative information about GOM concentration in the plume. 


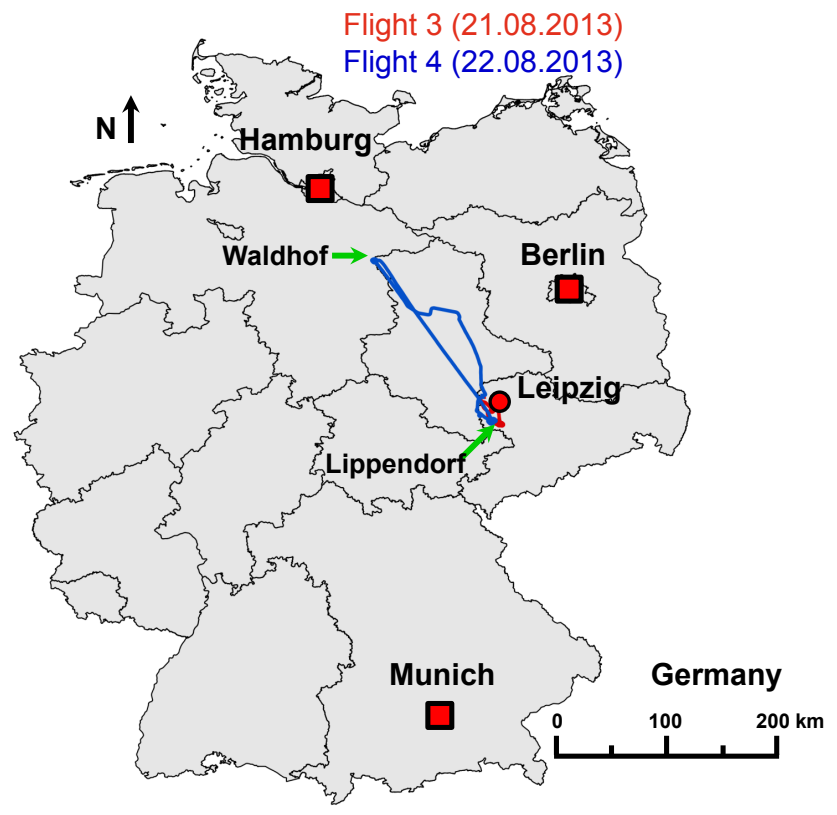

Figure 2. Flight tracks of the ETMEP-2 measurement flights, numbers 3 and 4, over central and northern Germany. The flights were made from the Leipzig airport.

We note that both methods used here to estimate GOM concentrations are subject to interferences. GOM captured by quartz wool can be released by higher air humidity (Ambrose et al., 2015) and $\mathrm{KCl}$ traps and denuders can release GOM in the presence of high ozone and water concentrations (Lyman et al., 2010; Huang and Gustin, 2015). These interferences may result in overestimation of GEM and underestimation of GOM emissions. GEM measured by Lumex is not subject to any known interference.

For the identification and characterization of different air masses carbon monoxide $(\mathrm{CO})$, ozone $\left(\mathrm{O}_{3}\right)$, sulphur dioxide $\left(\mathrm{SO}_{2}\right)$, nitrogen oxide $(\mathrm{NO})$, nitrogen dioxide $\left(\mathrm{NO}_{2}\right)$, and the basic meteorological parameters temperature $(T)$, pressure $(p)$, and relative humidity $(\mathrm{rH})$ were measured simultaneously with high temporal resolution. Instrument details, including the estimated measurement uncertainty, are summarized in Table 1. Uncertainties were calculated according to the individual instrument uncertainty given by the manufacturer and the calibration gas accuracy $\left(\mathrm{CO}, \mathrm{O}_{3}, \mathrm{SO}_{2}, \mathrm{NO}\right)$. All instruments were protected from aerosols using PTFE filters $(0.2 \mu \mathrm{m}$ pore size $)$. Model meteorological data, such as potential vorticity, equivalent potential temperature, relative and specific humidity, cloud cover, cloud water content, three-dimensional wind vector, as well as 5 day backward trajectories, were calculated every $150 \mathrm{~s}$ along the aircraft flight tracks for additional information. These calculations are based on meteorological analysis data from the European Centre for Medium-Range Weather Forecasts (ECMWF) and the TRAJKS trajectory model (Scheele et al., 1996).
Before takeoff all instruments were warmed up for at least 45 min using an external ground power supply. During the starting of the engines the power was interrupted for less than $3 \mathrm{~min}$. Since $45 \mathrm{~min}$ were too short to stabilize the Tekran 2537 internal permeation source, the Tekran instruments were calibrated only after each measurement flight before the engine shut down using the internal permeation source. All data were recalculated, using the post-flight calibrations. Before and after the ETMEP-2 campaign the permeation rate of the internal permeation source was checked by manual injection of a known amount of mercury from an external mercury source (Tekran 2505 unit). During the instrument warmup, takeoff, and landing a Tekran active carbon zero air cartridge was inserted upstream of the Tekran instruments to prevent their contamination by the usually dirty air around airports and to enable their zeroing. All mercury instruments reported zero mercury concentration while the cartridge was inserted. The pressure in the fluorescent cells of both Tekran instruments was kept constant using upstream pressure controllers at the exits of the cells. This eliminated the known pressure dependence of the response signal (Ebinghaus and Slemr, 2000; Radke et al., 2007). The Lumex analyzer has a much shorter warmup time of less than $10 \mathrm{~min}$ and was, therefore, calibrated before takeoff with the internal calibration cell consisting of a sealed quartz cylinder filled with air and saturated with mercury vapor. Unfortunately, the Lumex analyzer does not provide the option to verify the internal calibration by injection of mercurysaturated air from an external source. However, a comparison of the used Tekran- and Lumex mercury analyzers before and after the ETMEP-2 campaign showed a good agreement with a difference of less than $5 \%$. The $\mathrm{CO}$ instrument calibration takes $60 \mathrm{~s}$ and was, therefore, performed every $20 \mathrm{~min}$ with external calibration gas during the flights. The $\mathrm{O}_{3}, \mathrm{SO}_{2}$, and $\mathrm{NO} / \mathrm{NO}_{2}$ instruments have a fairly constant signal response and were thus calibrated before and after the ETMEP-2 measurement campaign. Multipoint $\mathrm{SO}_{2}$ and NO calibrations were made using dilution (Environics 300E calibrator) of certified standard gases. $\mathrm{NO}_{2}$ conversion efficiency was determined using gas phase titration. The factory calibration was used for the pressure, temperature, and relative humidity sensors. The measurements were synchronized using their individual delay and response times. Please note that all mercury (TGM, GEM, and GOM) concentrations are reported at standard temperature and pressure (STP; $T=273.15 \mathrm{~K}, p=1013.25 \mathrm{hPa})$. At these standard conditions $1 \mathrm{ng} \mathrm{m}^{-3}$ corresponds to a mixing ratio of $112 \mathrm{ppqv}$ (parts per quadrillion by volume).

\section{Vertical distribution and $\mathrm{Hg} / \mathrm{SO}_{2}, \mathrm{Hg} / \mathrm{CO}$, $\mathrm{NO}_{x} / \mathrm{SO}_{2}$ emission ratios}

The measurements were carried out on 21 and 22 August 2013. On 21 August between 09:30 and 11:20 UTC the air- 


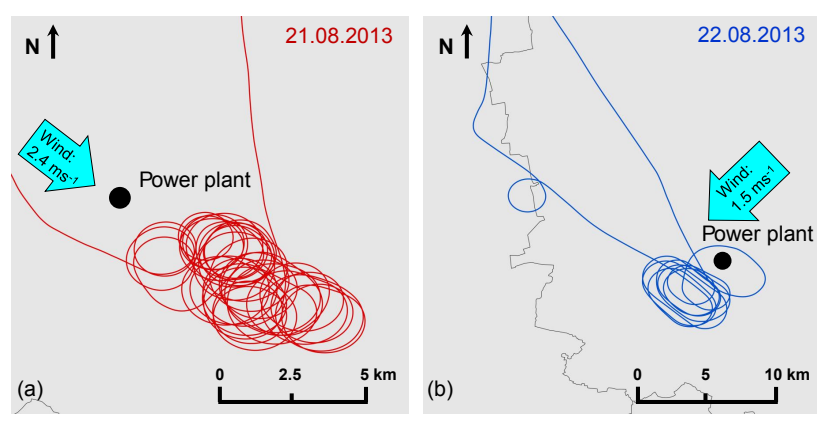

Figure 3. Flight tracks of the ETMEP-2 flights on 21 (a) and 22 (b) August 2013, downwind of the lignite-fired power plant, Lippendorf, south of Leipzig, Germany. On both flights the power plant plume was crossed several times.

craft flew many circles at different altitudes downwind of the Lippendorf CFPP $\left(51^{\circ} 11^{\prime} \mathrm{N}, 12^{\circ} 22^{\prime} \mathrm{E}\right)$ followed between 11:25 and 12:20 UTC by a vertical profile upwind of the Lippendorf CFPP, over the city center of Leipzig $\left(51.353^{\circ} \mathrm{N}\right.$, $12.434^{\circ} \mathrm{E}$ ). Between 08:30 and 10:00 UTC on 22 August another vertical profile above the GMOS master site "Waldhof" $\left(52^{\circ} 48^{\prime} \mathrm{N}, 10^{\circ} 45^{\prime} \mathrm{E}\right.$, about $200 \mathrm{~km}$ from Leipzig on the line connecting Leipzig and Hamburg) was flown, followed between 10:00 and 10:35 UTC by additional measurements downwind of the CFPP Lippendorf. Each vertical profile consists of at least seven horizontal flight legs, consisting of circles, and altogether lasting 5-10 min each. The flight legs started inside the boundary layer at about $400 \mathrm{~m}$ above ground and ended at $3000 \mathrm{~m}$ a.s.l. The tracks of the flights on 21 and 22 August are shown in Figs. 2 and $3 a$ and b, respectively. The CFPP plume was encountered at a distance of $\sim 7.5 \mathrm{~km}$ from the plant at an altitude of $1900 \mathrm{~m}$ a.s.l. on 21 August and in the distance of $\sim 5 \mathrm{~km}$ at $1500-1650 \mathrm{~m}$ a.s.l. on 22 August. With a wind speed of 2.4 and $1.5 \mathrm{~m} \mathrm{~s}^{-1}$ on 21 and 22 August, respectively, the age of the plume was $\sim 0.9 \mathrm{~h}$ on both days.

Figures 4 and 5 show data from the flight sections with CFPP plume encounters on 21 and 22 August 2013, respectively. The plume encounters lasted 1-2 min and are clearly indicated by elevated $\mathrm{SO}_{2}, \mathrm{NO}_{x}\left(\mathrm{NO}_{x}=\mathrm{NO},+, \mathrm{NO}_{2}\right)$, and GEM concentrations measured by Lumex. $\mathrm{CO}$ and $\mathrm{rH}$ enhancements are hardly visible on 21 August but are clearly recognizable on 22 August. Tekran instruments with a temporal resolution of $150 \mathrm{~s}$ are too slow to resolve individual plume encounters but they also show a broad peak of enhanced GEM (Tekran 1 with a quartz wool trap) or TGM (Tekran 2) concentrations. The difference between TGM measured by Tekran without a quartz wool trap and GEM measured by Tekran with a quartz wool trap is small (on average $0.087 \pm 0.117 \mathrm{ng} \mathrm{m}^{-3}(n=8)$ on 21 August and $0.063 \pm 0.079 \mathrm{ng} \mathrm{m}^{-3}(n=12)$ on 22 August $)$ and varies between -0.064 and $+0.354 \mathrm{ng} \mathrm{m}^{3}$ on both days. The average differences are not significantly different from zero and neither do the maximum and minimum differences exceed the combined uncertainty of the difference of $17.7 \%$. On 21 August the plume was encountered several times at an altitude between 1600 and $2500 \mathrm{~m}$ a.s.l. The most pronounced encounters numbered 1-4 were found at an altitude of 1800-2250 m a.s.l. On 22 August the plume was encountered three times at a flight level of $1550 \mathrm{~m}$ and three times at $1650 \mathrm{~m}$ a.s.l. The numbered plume encounters were selected for quantitative evaluation.

Figure 6 shows the vertical distribution of the values measured downwind of the Lippendorf CFPP. The vertical profiles above Leipzig and Waldhof are discussed together with further profiles by Weigelt et al. (2016). In Fig. 6 the squares represent the constant flight level measurement points ( 2 measurements with $2.5 \mathrm{~min}$ each). The stars represent the measurements when climbing between two flight levels ( $2.5 \mathrm{~min}$ average). The data indicated as squares are, therefore, more significant and the data illustrated as stars provide additional information on the vertical structure. Please note that the $\mathrm{rH}$, air temperature $(T)$, and potential temperature $(\theta)$ are plotted with high temporal resolution ( $1 \mathrm{~s})$ in the rightmost panel. The $\mathrm{rH}$ can be used to distinguish between boundary layer- and free tropospheric air. Inside the planetary boundary layer (PBL) the relative humidity is usually much higher than in the free troposphere (Spencer and Braswell, 1996).

The lower four horizontal flight legs (570 to $1340 \mathrm{~m}$ a.s.1.) show typical northern hemispheric GEM and TGM background concentration of $\sim 1.6 \mathrm{ng} \mathrm{m}^{-3}$ without any vertical gradient. $\mathrm{CO}, \mathrm{O}_{3}, \mathrm{SO}_{2}$, as well as $\mathrm{NO}$ and $\mathrm{NO}_{2}$ also show no vertical gradient, indicating a well-mixed PBL. This is in agreement to the other vertical profiles measured during the ETMEP-2 campaign (Weigelt et al., 2016). From the fifth flight leg (1630 ma.s.l.) upward, the GEM and TGM concentration increases towards the PBL top (GEM (Tekran 1): 1.7 at 1630 and 2.6 at 1940; TGM (Tekran 2): 1.7 at 1630 and 2.8 at 1940; GEM (Lumex): 2.1 at 1630 and $2.4 \mathrm{ng} \mathrm{m}^{-3}$ at $1940 \mathrm{~m}$ a.s.1.). The increasing concentration is also captured by the measurements during the flight level change (GEM (Tekran 1): 1.7 at 1540; 2.1 at 1800; TGM (Tekran 2): 1.7 at 1540; 2.3 at 1800; GEM (Lumex): 1.8 at $1540 ; 2.2 \mathrm{ng} \mathrm{m}^{-3}$ at $1800 \mathrm{~m}$ a.s.l.; stars in Fig. 5). As indicated by the abrupt decrease of $\mathrm{rH}$, the PBL top was found at 2150 to $2200 \mathrm{~m}$ a.s.l. Consequently, flight leg 7 at $2260 \mathrm{~m}$ a.s.l. and leg 8 at $3020 \mathrm{~m}$ a.s.l. were performed in free tropospheric air. These two measurements show a typical free-tropospheric background concentration $\left(\sim 1.3 \mathrm{ng} \mathrm{m}^{-3}\right.$; Weigelt et al., 2016 and references therein). The measurements during the flight level change from leg 6 to leg 7 and represent a mixture of boundary layer- and free-tropospheric air (averaged altitude $2150 \mathrm{~m}$ a.s.l.). Therefore GEM (Tekran 1), TGM (Tekran 2), and GEM (Lumex) concentrations of $2.3,2.4$, and $1.9 \mathrm{ng} \mathrm{m}^{-3}$ were strongly influenced by the high concentration below the boundary layer top. 


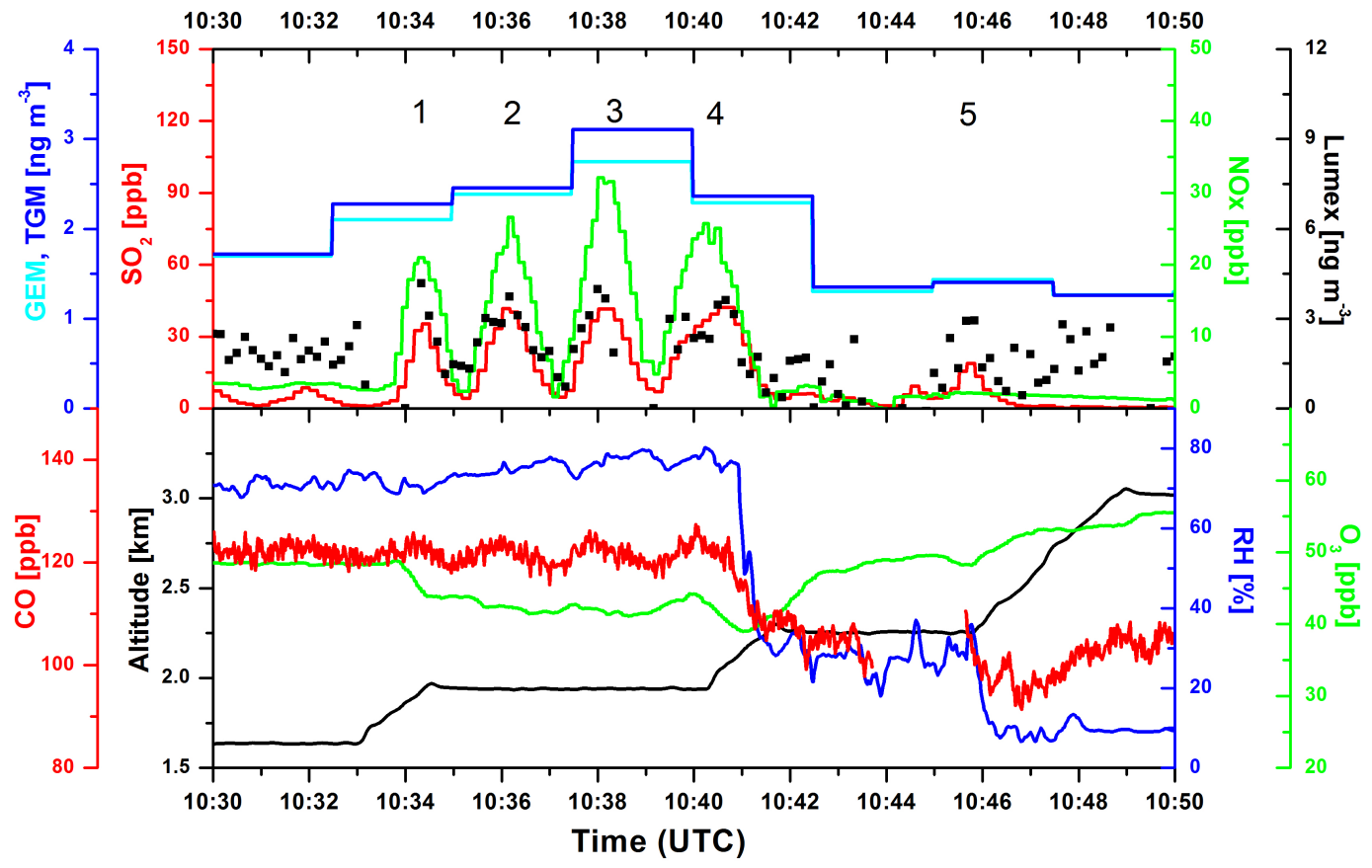

Figure 4. ETMEP-2 lignite-fired power plant plume measurements on 21 August 2013 south of Leipzig, Germany. The gaps in the Lumex signal (10 s resolution) are due to internal zero air checks for the correction of the baseline drift of the instruments. GEM was measured using a Tekran instrument run with a quartz wool trap at the inlet of the instrument, which is presumed to remove GOM. TGM was measured by another Tekran instrument with no quartz wool trap at the inlet. All parameters were synchronized using individual instrument delay and response times. All $\mathrm{Hg}$ concentrations are given at standard temperature and pressure (STP; $T=273.15 \mathrm{~K}, p=1013.25 \mathrm{hPa}$ ).

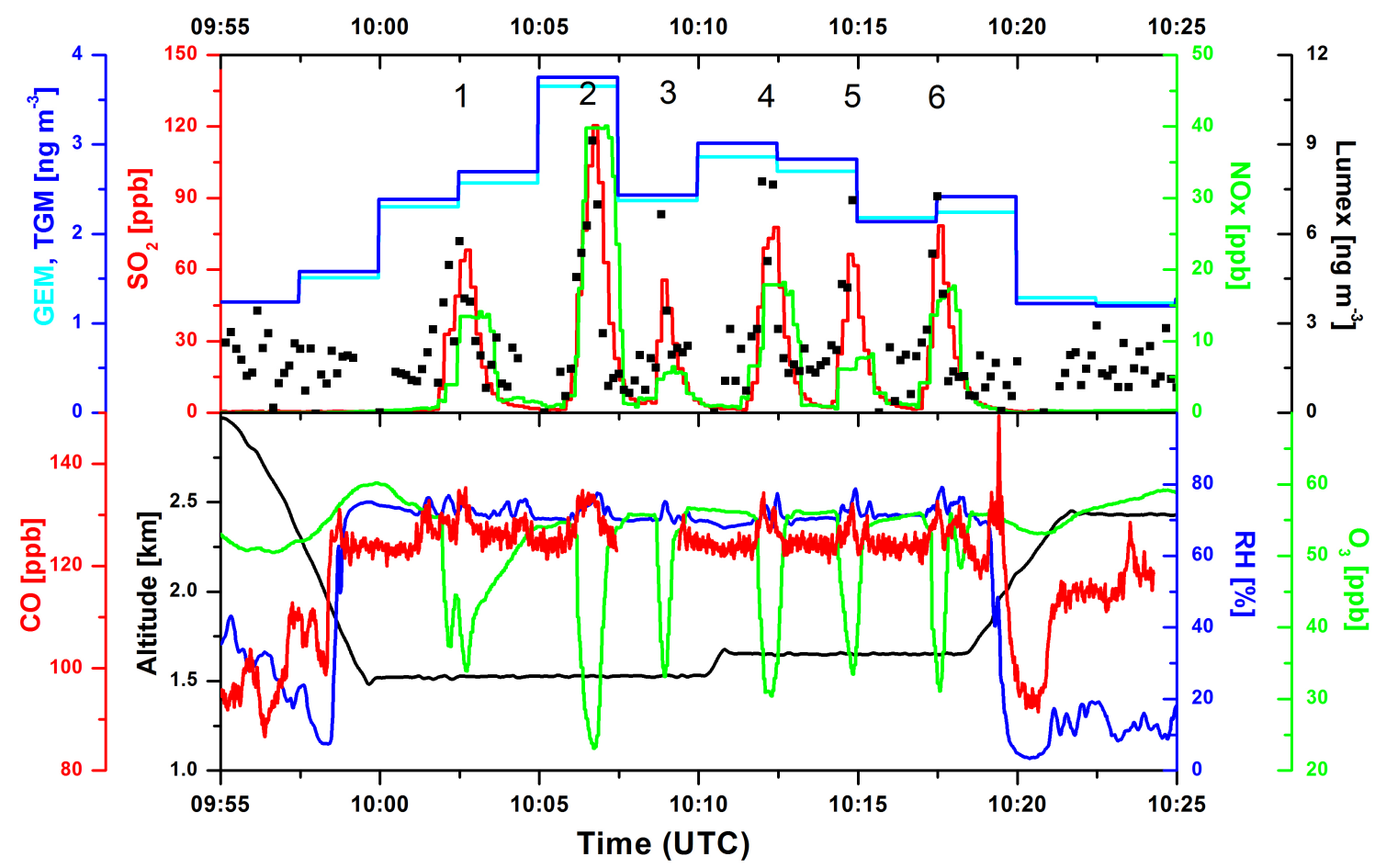

Figure 5. The same as in Fig. 4, but for measurements on 22 August 2013. 


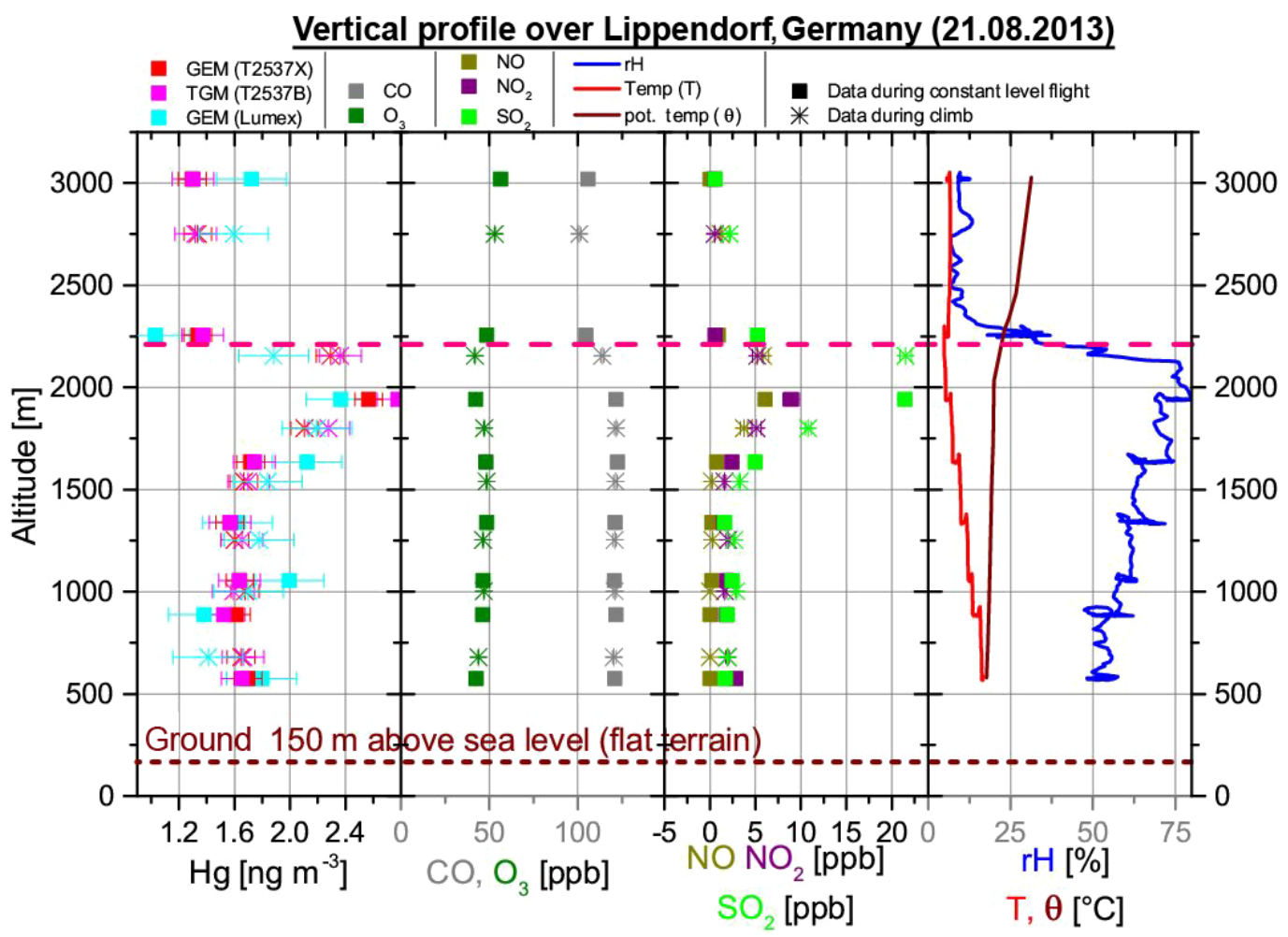

Figure 6. Vertical profile, measured on 21 August 2013 from 13:17:30 to 14:07:30 (local time) downwind from the coal-fired power plant, Lippendorf (central Germany; $45.561^{\circ} \mathrm{N}, 14.858^{\circ} \mathrm{E}$; elevation: $150 \mathrm{~m}$ a.s.l.; flat terrain). Squares represent $300 \mathrm{~s}$ averages with horizontal flight leg and stars indicate $150 \mathrm{~s}$ averages during climbing between two neighboring flight legs. The red dashed line indicates the planetary boundary layer (PBL) top, which was determined to be at 2150 to $2250 \mathrm{~m}$ a.s.l. All $\mathrm{Hg}$ concentrations are given at standard temperature and pressure (STP; $T=273.15 \mathrm{~K}, p=1013.25 \mathrm{hPa}$ ).

In the altitude range 1600 to $2200 \mathrm{~m}$ a.s.l. not only mercury, but also $\mathrm{SO}_{2}$ was significantly increased (from 1.6 to $21.4 \mathrm{ppb}$ ), which clearly indicates that the mercury was emitted from the CFPP. Inside the plume (leg 6), the $\mathrm{O}_{3}$ concentration was slightly decreased to $42.3 \mathrm{ppb}$. At the same time $\mathrm{NO}$ and $\mathrm{NO}_{2}$ increased to 6.1 and $8.9 \mathrm{ppb}$, respectively. Outside the plume (e.g., leg 4) $\mathrm{O}_{3}$ was $48.5 \mathrm{ppb}$, NO was below the detection limit, and $\mathrm{NO}_{2}$ was $\sim 1.5 \mathrm{ppb}$. This indicates $\mathrm{O}_{3}$ depletion due to NO oxidation inside the plume (cf. Figs. 4 and 5). The presence of a temperature inversion at the PBL top is indicated by the changing $T$ and $\theta$ vertical gradient in Fig. 6. This inversion layer prevents a further ascent of the power plant plume and, consequently, the highest concentration of pollutants was found below the PBL top. As already shown in Figs. 4 and 5, during a flight leg in a certain altitude (and during level change), the aircraft did not remain within the plume all the time. Therefore, the concentrations given in Fig. 6 do represent a mixture of plume and background air.

The ratio of concentration enhancements (ERs), $\Delta \mathrm{Hg} / \Delta \mathrm{SO}_{2}, \Delta \mathrm{Hg} / \Delta \mathrm{CO}$, and $\Delta \mathrm{NO}_{x} / \Delta \mathrm{SO}_{2}$ represent the emission ratios at the stack if (a) chemical reactions during the transport from the stack to the point of interception can be neglected and (b) the background concentrations have not changed during the measurement, including the transport from the stack to the place of plume encounters. As mentioned above, the transport time from the stack to the location of plume interception was $\sim 0.9 \mathrm{~h}$ on both days. Based on $\mathrm{OH}$ concentrations measured in a CFPP plume, Ambrose et al. (2015) estimated $\mathrm{SO}_{2}$ and $\mathrm{NO}_{x}$ lifetimes of $16-43$ and $1.8-5.8 \mathrm{~h}$, respectively. The combination of GEM, TGM, and GOM measurements by Lumex, Tekran 2537X (Tekran 1, with a quartz wool trap), 2537B (Tekran 2, without a quartz wool trap), and $\mathrm{KCl}$ denuder, respectively, suggests that there is no substantial conversion of GEM into GOM within the transport time of $\sim 0.9 \mathrm{~h}$. The vertical profile over Leipzig, upwind of the CFPP, was measured on 21 August ca. $1 \mathrm{~h}$ after the measurements in the plume. The $\mathrm{CO}, \mathrm{O}_{3}, \mathrm{SO}_{2}, \mathrm{NO}_{x}$, and $\mathrm{Hg}$ concentrations in the PBL over Leipzig with $\sim 120,50,0.5,3 \mathrm{ppb}, 1.4 \mathrm{ng} \mathrm{m}^{-3}$, respectively, are similar to respective concentrations found outside of the plume over the Lippendorf CFPP. Differences between them for $\mathrm{SO}_{2}, \mathrm{NO}_{x}$, and $\mathrm{Hg}$ are small when compared with their enhancements in the plumes of $\sim 40,30 \mathrm{ppb}$, and $4 \mathrm{ng} \mathrm{m}^{-3}$, respectively. On 22 August no vertical profile upwind was measured, but $\mathrm{SO}_{2}, \mathrm{NO}_{x}$, and $\mathrm{Hg}$ concentrations over Waldhof, $\sim 90 \mathrm{~km}$ north of Leipzig, measured 
immediately before the downwind measurements of the Lippendorf CFPP, were comparable. We thus conclude that the background concentrations of $\mathrm{SO}_{2}, \mathrm{NO}_{x}$, and $\mathrm{Hg}$ had not changed significantly during the $0.9 \mathrm{~h}$ long transport from the stack to the location of aircraft interception or during $\sim 20 \mathrm{~min}$ of the repeated plume interceptions. In addition, the large $\mathrm{SO}_{2}, \mathrm{NO}_{x}$, and $\mathrm{Hg}$ enhancements in the plume make the calculated $\Delta \mathrm{Hg} / \Delta \mathrm{SO}_{2}$ and $\Delta \mathrm{NO}_{x} / \Delta \mathrm{SO}_{2}$ ERs insensitive to small changes in background $\mathrm{SO}_{2}, \mathrm{NO}_{x}$, and $\mathrm{Hg}$ concentrations. This is not always the case for small $\Delta \mathrm{CO}$ and negative $\Delta \mathrm{O}_{3}$ (negative because $\mathrm{O}_{3}$ is consumed by rapid oxidation of $\mathrm{NO}$ to $\mathrm{NO}_{2}$ ) relative to their background mixing ratios. In addition, the $\mathrm{CO}$ background mixing ratios changed substantially from $\sim 123$ to $105 \mathrm{ppb}$ during plume crossings 4 and 5 on 21 August due to altitude change. $\Delta \mathrm{Hg} / \Delta \mathrm{CO}$ for these plume interceptions was thus not calculated.

The ERs are usually calculated at a slope of $\mathrm{Hg}$ vs. $X$ correlations (e.g., Ambrose et al., 2015). The advantage of this method is that the background concentrations of neither $\mathrm{Hg}$ nor $X$ have to be known as long as they remain constant during the measurement. The method, however, is applicable only if the plume crossings are much longer than the response time of the instruments. With the plume transects lasting in our case only $60-120 \mathrm{~s}$ and effective temporal resolution of $10 \mathrm{~s}$ for $\mathrm{SO}_{2}$ and $\mathrm{NO}_{x}$ measurements, however, the signals have to be carefully synchronized. In addition, the correlation slopes for individual plume crossings will become quite uncertain because of the small number of points. For this reason we apply the correlation method for all (synchronized) points with $\mathrm{SO}_{2}$ mixing ratios $>10 \mathrm{ppb}$. This selection provides 35 and 45 points for $\mathrm{Hg}$ vs. $\mathrm{SO}_{2}$ correlations on 21 and 22 August, respectively. Individual plume crossings are not resolved by this calculation. Correlations made by the bivariate Williamson-York method (Cantrell, 2008) provide a slope and its statistical uncertainty representing ER $\left(\mathrm{Hg} / \mathrm{SO}_{2}\right)$ and its uncertainty.

An alternative method calculates ERs as a ratio of $\Delta \mathrm{Hg}$ to $\Delta X$ where $\Delta \mathrm{Hg}$ and $\Delta X$ are signal enhancements against the background integrated over the plume crossing. This method, called here the "integral method", is applicable for measurements with instruments with different response times and we will show that it can use even Tekran measurements with a temporal resolution of $150 \mathrm{~s}$, although not for individual plume crossings. Opposite to the correlation method, no exact synchronization is needed. The disadvantage, however, is that the results are sensitive to the selection of background concentrations. Figures 4 and 5 show that background $\mathrm{Hg}$ concentrations are especially difficult to define from the Lumex measurements. We thus use the Hg background concentrations measured by the more precise Tekran instrument. As the Lumex instrument measured only GEM, we use the background measured by the Tekran instrument with quartz wool (Tekran 1). The other disadvantage of the integral method is that, opposite to the correlation method, the uncertainty of ERs is difficult to quantify. We overcome this difficulty here by averaging the ERs from individual plume crossings and taking their standard deviation as a measure of ER uncertainty.

The $\mathrm{Hg} / \mathrm{SO}_{2}$ ERs are listed in Table 2. The correlation and integral methods provide similar results with $5.53 \pm 1.10$ and $5.56 \pm 1.19 \mu \mathrm{mol} \mathrm{mol}^{-1}$, respectively, for 21 August, and $7.38 \pm 0.92$ and $6.32 \pm 1.52 \mu \mathrm{mol} \mathrm{mol}^{-1}$, respectively, for 22 August. The integral method with TGM (Tekran 2) and $\mathrm{SO}_{2}$ integrals over all plume encounters provide somewhat higher $\mathrm{Hg} / \mathrm{SO}_{2}$ ERs but still within the uncertainties of the correlation and integral methods. The measured $\mathrm{Hg} / \mathrm{SO}_{2}$ ERs are smaller than the emission ratio of $10.8 \mu \mathrm{mol} \mathrm{mol}^{-1}$ calculated from $\mathrm{Hg}$ and $\mathrm{SO}_{2}$ annual emissions reported by the CFPP operator for 2013. They are close to 5.2-6.5 $\mathrm{mol} \mathrm{mol}^{-1}$ determined by Ambrose et al. (2015) for Big Brown (BBS) and Dolet Hills Stations (DHS). BBS, a 1187 MW CFPP in Texas, is fired with sub-bituminous coal and is equipped with activated carbon injection flue cleaning. DHS, a 721 MW CFPP in Louisiana, is fired with lignite and is equipped with wet FGD, similar to the FGD of the Lippendorf CFPP.

$\mathrm{Hg} / \mathrm{CO}$ ERs are frequently used to classify the origin of different plumes (Slemr et al., 2009, 2014; Lai et al., 2011, and references therein) with ERs $<0.25 \mu \mathrm{mol} \mathrm{mol}^{-1}$ typical for plumes from biomass burning and ERs $>0.6 \mu \mathrm{mol} \mathrm{mol}^{-1}$ characteristic for plumes of urban/industrial origin. The $\mathrm{Hg} / \mathrm{CO}$ ERs measured in the plume of the Lippendorf CFPP are listed in Table 3. The correlation method tends to yield somewhat higher $\mathrm{Hg}$ / CO ERs than the integral method. Because of changing background on 21 August and changing altitude on 22 August, no ERs were calculated by the integral method using the Tekran measurements. As mentioned before, the high background $\mathrm{CO}$ mixing ratios and relatively small $\mathrm{CO}$ enhancement in the plume make the integral method quite sensitive to the chosen background. For this reason we believe 5.2 and $9.4 \mu \mathrm{mol} \mathrm{mol}^{-1}$ from correlation method for 21 and 22 August, respectively, to be more reliable. The $\mathrm{Hg} / \mathrm{CO}$ emission ratio from the 2013 annual emissions reported by the operator is $7.6 \mu \mathrm{mol} \mathrm{mol}^{-1}$, in reasonable agreement with our measurements. $\mathrm{Hg}$ / CO ERs of this magnitude have never been observed in the plumes detected during the CARIBIC (Civil Aircraft for the Regular Investigation of the Atmosphere Based on an Instrument Container) flights (Slemr et al., 2014). This is probably because only large plumes extending over several hundreds to thousands of $\mathrm{km}$ can be detected by these flights. Their $\mathrm{Hg} / \mathrm{CO}$ ERs are then a mixture of $\mathrm{Hg} / \mathrm{CO}$ ERs from point sources embedded in plumes from larger industrial and/or urban areas.

Simultaneous $\mathrm{NO}_{x}$ and $\mathrm{SO}_{2}$ measurements allow us to calculate also the $\mathrm{NO}_{x} / \mathrm{SO}_{2}$ ERs, which are listed in Table 4. The ERs from the correlation and integral methods are in good agreement with each other on both days. The $\mathrm{NO}_{x} / \mathrm{SO}_{2}$ ER of $0.59 \mathrm{~mol} \mathrm{~mol}^{-1}$ on 21 August is al- 
Table 2. $\mathrm{Hg} / \mathrm{SO}_{2}$ enhancement ratios (ERs). Correlation method: $10 \mathrm{~s}$ average $\mathrm{Hg}$ concentrations measured by Lumex correlated with $10 \mathrm{~s}$ average $\mathrm{SO}_{2}$ mixing ratios. Only $\mathrm{Hg}$ values with $\mathrm{SO}_{2}$ concentrations $>10 \mathrm{ppb}$ were taken with uncertainties set to $1 \mathrm{ng} \mathrm{m}^{-3}$ for Lumex and $0.5 \mathrm{ppb}$ for $\mathrm{SO}_{2}$. Integral method: $1 \mathrm{~s}$ Lumex and $\mathrm{SO}_{2}$ signals integrated over the duration of Lumex measurement, measurements of Tekran with quartz wool taken as Lumex background concentrations (i.e., 1.27 and $1.25 \mathrm{ng} \mathrm{m}^{-3}$ for 21 and 22 August, respectively). SO background mixing ratio was 0.83 and $0.66 \mathrm{ppb}$ on 21 and 22 August, respectively. Since Tekran with a temporal resolution of $150 \mathrm{~s}$ cannot resolve individual plume crossing, the integral of the Tekran signal encompasses the plumes $1-4$ on 21 August and the plumes 1-6 on 22 August.

\begin{tabular}{|c|c|c|c|c|c|}
\hline Date & Method & Species & $\begin{array}{l}\mathrm{ER} \\
10^{-6} \mathrm{~mol} \mathrm{~mol}^{-1}\end{array}$ & $n, R$, signif & Comment \\
\hline \multirow[t]{9}{*}{21 August 2013} & correlation & GEM & $5.53 \pm 1.10$ & $\begin{array}{l}35,0.6564 \\
>99.9 \%\end{array}$ & \\
\hline & integral peak 1 & GEM & 6.67 & & $\begin{array}{l}\text { Lumex } \\
\text { zeroing }\end{array}$ \\
\hline & integral peak 2 & GEM & 5.72 & & \\
\hline & integral peak 3 & GEM & 5.98 & & $\begin{array}{l}\text { Lumex } \\
\text { zeroing }\end{array}$ \\
\hline & integral peak 4 & GEM & 3.88 & & \\
\hline & integral peak 5 & GEM & 0.89 & & \\
\hline & integral average & GEM & $5.56 \pm 1.19^{*}$ & $4^{*}$ & \\
\hline & $\begin{array}{l}\text { Tekran with } \\
\text { quartz wool trap }\end{array}$ & GEM & 6.56 & & \\
\hline & $\begin{array}{l}\text { Tekran without quartz wool trap } \\
\text { quartz wool trap }\end{array}$ & TGM & 7.55 & & \\
\hline \multirow[t]{10}{*}{22 August 2013} & correlation & GEM & $7.38 \pm 0.92$ & $\begin{array}{l}45,0.7751 \\
>99.9 \%\end{array}$ & \\
\hline & integral peak 1 & GEM & 6.44 & & \\
\hline & integral peak 2 & GEM & 4.83 & & \\
\hline & integral peak 3 & GEM & 5.90 & & $\begin{array}{l}\text { Lumex } \\
\text { zeroing }\end{array}$ \\
\hline & integral peak 4 & GEM & 6.67 & & \\
\hline & integral peak 5 & GEM & 9.03 & & $\begin{array}{l}\text { Lumex } \\
\text { zeroing }\end{array}$ \\
\hline & integral peak 6 & GEM & 5.02 & & \\
\hline & integral average & GEM & $6.32 \pm 1.52$ & 6 & \\
\hline & $\begin{array}{l}\text { Tekran with } \\
\text { quartz wool trap }\end{array}$ & GEM & 8.13 & & \\
\hline & $\begin{array}{l}\text { Tekran without } \\
\text { quartz wool trap }\end{array}$ & TGM & 8.97 & & \\
\hline 2013 & $\begin{array}{l}\text { reported annual emissions } \\
\text { emissions }\end{array}$ & TGM & 10.8 & & \\
\hline
\end{tabular}

* Average without integral of peak 5, which is identified as outlier by Nalimov test (at >95\% significance level, Kaiser and Gottschalk, 1972).

most twice as large as $0.27 \mathrm{~mol} \mathrm{~mol}^{-1}$ on 22 August, and both ERs are substantially lower than the emission ratio of $0.91 \mathrm{~mol} \mathrm{~mol}^{-1}$ calculated from the $\mathrm{NO}_{x}$ and $\mathrm{SO}_{2}$ emissions reported by the CFPP operator for 2013. All these $\mathrm{NO}_{x} / \mathrm{SO}_{2}$ ERs are substantially larger than $\sim 0.08 \mathrm{~mol} \mathrm{~mol}^{-1}$ reported by Ambrose et al. (2015) for Big Brown CFPP in Texas and corrected for the $\mathrm{NO}_{x}$ loss during transport from the stack to the point of the plume interception.

Ozone is not emitted but the ambient $\mathrm{O}_{3}$ is consumed by a rapid reaction with $\mathrm{NO}\left(\mathrm{O}_{3}+\mathrm{NO}=\mathrm{NO}_{2}+\mathrm{O}_{2}\right)$ in the plume during the transport from the stack to the point of plume interception. The $\mathrm{O}_{3} / \mathrm{NO}_{x}$ ERs thus do not repre- sent emission ratios and they are negative because of $\mathrm{O}_{3}$ consumption. If only $\mathrm{NO}$ were emitted the $\mathrm{O}_{3} / \mathrm{NO}_{x} \mathrm{ER}$ would be $-1 \mathrm{~mol} \mathrm{~mol}^{-1} . \mathrm{O}_{3} / \mathrm{NO}_{x}$ ERs were not calculated for 21 August because of changing $\mathrm{O}_{3}$ background mixing ratios. The calculated $\mathrm{O}_{3} / \mathrm{NO}_{x}$ ERs for 22 August are listed in Table 5. The correlation method provides a slope of $-0.62 \pm 0.13 \mathrm{~mol} \mathrm{~mol}^{-1}$ while the integral method provides an ER of $-1.0 \pm 0.6 \mathrm{~mol} \mathrm{~mol}^{-1}$. We thus conclude that the emitted NO constitute some $60-100 \%$ of $\mathrm{NO}_{x}$ emissions. 
Table 3. $\mathrm{Hg}$ / CO enhancement ratios (ERs). Correlation method: $10 \mathrm{~s}$ average $\mathrm{Hg}$ concentrations measured by Lumex correlated with $10 \mathrm{~s}$ average $\mathrm{CO}$ mixing ratios for $\mathrm{SO}_{2}$ mixing ratios above $10 \mathrm{ppb}$ with uncertainties set to $1 \mathrm{ng} \mathrm{m}^{-3}$ for Lumex and $1 \mathrm{ppb}$ for CO. Integral method: $1 \mathrm{~s}$ Lumex and CO signals integrated over the duration of Lumex measurement, readings of Tekran with quartz wool taken as Lumex background concentrations (i.e., 1.27 and $1.25 \mathrm{ng} \mathrm{m}^{-3}$ for 21 and 22 August, respectively). CO background mixing ratio was $119.3 \mathrm{ppb}$ on 21 August and $123.8 \mathrm{ppb}$ on 22 August.

\begin{tabular}{|c|c|c|c|c|}
\hline \multirow[t]{2}{*}{ Date } & \multirow[t]{2}{*}{ Method } & \multicolumn{2}{|c|}{$\mathrm{ER}(\mathrm{Hg} / \mathrm{CO})$} & \multirow[t]{2}{*}{ Comment } \\
\hline & & $10^{-5} \mathrm{~mol} \mathrm{~mol}^{-1}$ & $n, R$, signif & \\
\hline \multirow[t]{7}{*}{21 August 2013} & Correlation & $5.19 \pm 0.94$ & $\begin{array}{l}31,0.6596 \\
>99.9 \%\end{array}$ & $\begin{array}{l}\text { values only until } \\
10: 40: 20\end{array}$ \\
\hline & integral peak 1 & 3.40 & & Lumex zeroing \\
\hline & integral peak 2 & 4.16 & & \\
\hline & integral peak 3 & 3.33 & & Lumex zeroing \\
\hline & integral peak 4 & & & $\begin{array}{l}\text { background } \\
\text { change }\end{array}$ \\
\hline & integral peak 5 & & & CO calibration \\
\hline & integral average & $3.63 \pm 0.46$ & 3 & \\
\hline \multirow[t]{8}{*}{22 August 2013} & Correlation & $9.43 \pm 1.07$ & $\begin{array}{l}37,0.7880 \\
>99.9 \%\end{array}$ & \\
\hline & integral peak 1 & 3.19 & & \\
\hline & integral peak 2 & & & CO calibration \\
\hline & integral peak 3 & & & Lumex zeroing, \\
\hline & integral peak 4 & 7.87 & & CU calıbration \\
\hline & integral peak 5 & 5.61 & & Lumex zeroing \\
\hline & integral peak 6 & 4.75 & & \\
\hline & integral average & $5.36 \pm 1.95$ & 4 & \\
\hline 2013 & $\begin{array}{l}\text { reported annual } \\
\text { emissions }\end{array}$ & 7.58 & & \\
\hline
\end{tabular}

\section{GOM emissions}

As mentioned earlier, the GOM measurements made here using quartz wool traps and $\mathrm{KCl}$ coated denuders can both be influenced by high humidity (Huang and Gustin, 2015) and those made by $\mathrm{KCl}$ can additionally be influenced by high $\mathrm{O}_{3}$ concentrations (Lyman et al., 2010). Because of NO emissions, the $\mathrm{O}_{3}$ concentrations in the CFPP plumes will be lower than in ambient air, making $\mathrm{O}_{3}$ interference unlikely. Humidity interference would lead to an underestimation of GOM concentrations measured by $\mathrm{KCl}$ denuders and overestimation of GEM concentrations measured by the Tekran instrument with the quartz wool trap. However, specific GEM measurements are provided by Lumex, an atomic absorption instrument with Zeeman background correction, albeit with a worse precision when compared to Tekran measurements.

Table 6 lists the GOM concentrations measured by the $\mathrm{KCl}$ denuders during the vertical profiles over Leipzig and in the plume of the Lippendorf CFPP on 21 August 2013, and over Waldhof on 22 August 2013. Taking into account the uncertainty of $\pm 5 \mathrm{pg} \mathrm{m}^{-3}$, there is hardly any difference between GOM concentration of $5.8 \mathrm{pg} \mathrm{m}^{-3}$ measured during the vertical profile over Leipzig and $11.4 \mathrm{pg} \mathrm{m}^{-3}$ in the plume of the Lippendorf CFPP on 21 August. The differ- ence of $5.6 \mathrm{pg} \mathrm{m}^{-3}$ is distributed over the vertical profile of $3000 \mathrm{~m}$. Vertical profile in Fig. 6 shows that the CFPP plume was about $450 \mathrm{~m}$ thick. Assuming nearly zero GOM concentrations outside of this layer, the GOM concentrations in the layer would be $\sim 40 \mathrm{pg} \mathrm{m}^{-3}$. This is roughly consistent with the differences between Tekran measurements without the quartz wool trap and with it. The average difference in the plume was $87 \pm 117 \mathrm{pg} \mathrm{m}^{-3}(n=8)$ on 21 August and $63 \pm 79 \mathrm{pg} \mathrm{m}^{-3}(n=12)$ on 22 August. Related to the average TGM enhancement (Tekran without a quartz wool trap) in the plume of 0.90 on 21 August and of $1.03 \mathrm{ng} \mathrm{m}^{-3}$ on 22 August, the GOM concentration would represent $\sim 10$ and $\sim 6 \%$ of TGM emissions on 21 and 22 August, respectively.

An independent assessment of the GOM emissions can be made using $\mathrm{Hg} / \mathrm{SO}_{2}$ ERs listed in Table 2. On 21 August, the $\mathrm{Hg} / \mathrm{SO}_{2} \mathrm{ER}$ of $5.5 \pm 1.1 \mu \mathrm{mol} \mathrm{mol}{ }^{-1}$ from correlation methods and $5.6 \pm 1.2 \mu \mathrm{mol} \mathrm{mol}^{-1}$ from integral methods, both based on specific GEM measurements by Lumex, are within their uncertainties consistent with $6.6 \mathrm{umol} \mathrm{mol}^{-1} \mathrm{de}$ rived from Tekran with the quartz wool trap. On 22 August, the $\mathrm{Hg} / \mathrm{SO}_{2}$ ER of $7.4 \pm 0.9 \mu \mathrm{mol} \mathrm{mol}^{-1}$ from the correlation method is consistent with $8.1 \mu \mathrm{mol} \mathrm{mol}^{-1}$ determined from Tekran data, while the $6.3 \pm 1.5 \mu \mathrm{mol} \mathrm{mol}^{-1}$ from the 
Table 4. $\mathrm{NO}_{x} / \mathrm{SO}_{2}$ enhancement ratios (ERs). Correlation method: $10 \mathrm{~s}$ average $\mathrm{NO}_{x}$ mixing ratios correlated with $10 \mathrm{~s}$ average $\mathrm{SO}_{2}$ mixing ratios above $10 \mathrm{ppb}$ with uncertainties set to $1 \mathrm{ppb}$ for $\mathrm{NO}_{x}$ and $0.5 \mathrm{ppb}$ for $\mathrm{SO}_{2}$. Integral method: $1 \mathrm{~s} \mathrm{NO}_{x}$ and $1 \mathrm{~s} \mathrm{SO} \mathrm{SO}_{2}$ signals integrated over the duration of the individual plume intersection. Background mixing ratios for $\mathrm{SO}_{2}$ and $\mathrm{NO}_{x}$ are 0.83 and $1.78 \mathrm{ppb}$, respectively, for 21 August and 0.66 and $0.45 \mathrm{ppb}$, respectively for 22 August.

\begin{tabular}{|c|c|c|c|c|}
\hline \multirow[t]{2}{*}{ Date } & \multirow[t]{2}{*}{ Method } & \multicolumn{2}{|c|}{$\mathrm{ER}\left(\mathrm{NO}_{x} / \mathrm{SO}_{2}\right)$} & \multirow[t]{2}{*}{ Comment } \\
\hline & & $\mathrm{mol} \mathrm{mol}^{-1}$ & $n, R$, signif & \\
\hline \multirow[t]{7}{*}{21 August 2013} & Correlation & $0.585 \pm 0.038$ & $\begin{array}{l}34,0.9379 \\
>99.9 \%\end{array}$ & \\
\hline & integral peak 1 & 0.598 & & \\
\hline & integral peak 2 & 0.575 & & \\
\hline & integral peak 3 & 0.725 & & \\
\hline & integral peak 4 & 0.497 & & \\
\hline & integral peak 5 & & & \\
\hline & integral average & $0.598 \pm 0.095$ & 4 & \\
\hline \multirow[t]{8}{*}{22 August 2013} & Correlation & $0.262 \pm 0.051$ & $\begin{array}{l}40,0.6344 \\
>99.9 \%\end{array}$ & \\
\hline & integral peak 1 & 0.297 & & \\
\hline & integral peak 2 & 0.457 & & \\
\hline & integral peak 3 & 0.167 & & Lumex zeroing \\
\hline & integral peak 4 & 0.330 & & \\
\hline & integral peak 5 & 0.133 & & Lumex zeroing \\
\hline & integral peak 6 & 0.317 & & \\
\hline & integral average & $0.284 \pm 0.118$ & 6 & \\
\hline 2013 & $\begin{array}{l}\text { reported annual } \\
\text { emissions }\end{array}$ & 0.910 & & \\
\hline
\end{tabular}

Table 5. $\mathrm{O}_{3} / \mathrm{NO}_{x}$ enhancement ratios (ERs). Correlation method: $10 \mathrm{~s}$ average $\mathrm{O}_{3}$ mixing ratios correlated with $10 \mathrm{~s}$ average $\mathrm{SO}_{2}$ mixing ratios above $10 \mathrm{ppb}$ with uncertainties set to $1 \mathrm{ppb}$ for $\mathrm{O}_{3}$ and $1 \mathrm{ppb}$ for $\mathrm{NO}_{x}$. Integral method: $1 \mathrm{~s} \mathrm{O}_{3}$ and $1 \mathrm{~s} \mathrm{NO}_{x}$ signals integrated over the duration of the individual plume intersection. Background mixing ratios for $\mathrm{O}_{3}$ and $\mathrm{NO}_{x}$ are 43.09 and $1.78 \mathrm{ppb}$, respectively, for 21 August. Individual $\mathrm{O}_{3}$ background mixing ratios (average of background before and after the peak) varying between 53.9 ppb for peak 1 and $56.2 \mathrm{ppb}$ for peak 4 were taken for 22 August. The $\mathrm{NO}_{x}$ background mixing ratio on 22 August was $0.45 \mathrm{ppb}$.

\begin{tabular}{|c|c|c|c|c|}
\hline \multirow[t]{2}{*}{ Date } & \multirow[t]{2}{*}{ Method } & \multicolumn{2}{|c|}{$\mathrm{ER}\left(\mathrm{O}_{3} / \mathrm{NO}_{x}\right)$} & \multirow[t]{2}{*}{ Comment } \\
\hline & & $\mathrm{mol} \mathrm{mol}^{-1}$ & $n, R$, signif & \\
\hline \multirow[t]{8}{*}{22 August 2013} & Correlation & $-0.620 \pm 0.134$ & $\begin{array}{l}40,-0.3776,>95 \% \\
>95 \%\end{array}$ & \\
\hline & integral peak 1 & -0.979 & & \\
\hline & integral peak 2 & -0.424 & & \\
\hline & integral peak 3 & -1.527 & & \\
\hline & integral peak 4 & -0.686 & & \\
\hline & integral peak 5 & -2.059 & & \\
\hline & integral peak 6 & -0.568 & & \\
\hline & integral average & $-1.040 \pm 0.633$ & 6 & \\
\hline
\end{tabular}

integral method is somewhat lower. Consequently, $\mathrm{Hg} / \mathrm{SO}_{2}$ ERs from less specific measurements with the quartz wool trap tend to be somewhat higher but within their combined uncertainties comparable with those derived from GEM specific Lumex measurements. A comparison of $\mathrm{Hg} / \mathrm{SO}_{2} \mathrm{ERs}$ measured by Tekran without and with the quartz wool trap implies GOM emissions representing 13 and $9 \%$ of TGM emissions on 21 August and 22, respectively. Taking GEM specific Lumex measurements instead of those made by Tekran with the quartz wool trap would imply GOM emissions representing 27 and $24 \%$ on 21 August and 22, respectively, which we consider an upper limit.

In summary, we conclude that GOM represented less than $25 \%$ of the TGM emitted from the Lippendorf CFPP on 21 and 22 August 2013. Schütze et al. (2015) provide no numerical value but their Figure 6 shows that GOM represented 
Table 6. Results of the manual $\mathrm{KCl}$ denuder samples during all ETMEP-2 measurement flights in 2013 over central Europe. GOM data were corrected for denuder blanks determined over Iskraba, Slovenia, and Waldhof, Germany. GOM concentrations are given as a center of an estimated uncertainty range (in brackets) and are given at standard temperature and pressure (STP; $T=273.15 \mathrm{~K}, p=1013.25 \mathrm{hPa})$.

\begin{tabular}{llll}
\hline Date & Location & $\begin{array}{l}\text { Profile character } \\
\text { (relative sampling time } \\
\text { in PBL }^{1} \text { and } \text { FT }^{2} \text { air }\end{array}$ & $\begin{array}{l}\text { analyzed GOM } \\
\text { concentration) } \\
{\left[\mathrm{pg} \mathrm{m}^{-3}\right]}\end{array}$ \\
\hline $2013-08-21$ & Lippendorf, Germany & vertical (76\% PBL: 24\% FT) & $11.4(7.0-15.7)$ \\
$2013-08-21$ & Leipzig, Germany & vertical (61\% PBL; 39\% FT) & $5.8\left(1.0^{3}-10.6\right)$ \\
$2013-08-22$ & Waldhof, Germany & vertical (54\% PBL; 46\% FT) & $31.0(24.6-37.3)$ \\
\hline
\end{tabular}

${ }^{1}$ Planetary boundary layer (PBL). ${ }^{2}$ Free troposphere (FT). ${ }^{3}$ If a concentration was found to be below the method lower detection limit of $1.0 \mathrm{pg} \mathrm{m}^{-3}$, the lower detection limit is given.

$\sim 20 \%$ of total mercury emissions of the Lippendorf CFPP at operating conditions in 2013, which is consistent with our measurements. Edgerton et al. (2006) reported GOM fractions of 13,19, and $21 \%$ of total mercury in the plumes from CFPPs Hammond, Crist, and Bowen in the US. Stergašek et al. (2008) reported $4 \%$ GOM fraction for $\mathrm{Hg}$ emissions from a CFPP with FGD in Slovenia that was fired by lignite. Wang et al. (2010) found GOM fractions of $6-25 \%$ of all $\mathrm{Hg}$ emissions from five Chinese power plants with FGD. Deeds et al. (2013) found $13 \%$ of total mercury being GOM in the plume of the Nanticoke CFPP in Canada. They think that discrepancy between this and the $43 \%$ GOM fraction found in stack gases is due to sampling biases. Tatum Ernest et al. (2014) support their findings using a speciation technique still in development. In comparison, Landis et al. (2014) report high GOM fractions of $>86 \%$ in stack gases of the Crist CFPP and 4-40\% conversion of GOM into GEM in the plume at a $0.6-1.3 \mathrm{~km}$ distance from the stack. They attribute the difference to a reduction of GOM to GEM during the plume transport. But the reduction during the plume transport cannot resolve the difference between 86 and $20 \%$ measured by Landis et al. (2014) and Schütze et al. (2015) directly in the stack of the Crist and Lippendorf CFPPs, respectively. We note that Fig. 7 of Schütze et al. (2015) shows a large dayto-day variation in mercury removal efficiency of the Lippendorf CFPP, which probably also applies to the GOM removal efficiency. Thus, part of the difference between GOM in stack gases of the Lippendorf CFPP and the Crist CFPP can result from day-to-day variations in GOM removal efficiency. Putting this unresolved issue aside, low fractions of GOM emissions reported here and by others (Edgerton et al., 2006; Stergašek et al., 2008; Wang et al., 2010; Deeds et al., 2013) are in contrast to the AMAP/UNEP geospatially distributed mercury emissions data set "2010v1" (Wilson et al., 2013), which splits the speciated mercury emissions from combustion in power plants to $50 \mathrm{GEM}, 40 \mathrm{GOM}$, and $10 \% \mathrm{PBM}$. As mentioned before, the FGD in the Lippendorf CFPP is made by washing the flue gas with $\mathrm{CaO}$ suspension with added sulfidic precipitant. This type of FGD is known to capture most of GOM (Schütze, 2013). Although no PBM was measured in this study, $10 \%$ of mercury being emitted as PBM, according to the inventory, is probably also an overestimation for CFPPs with FGD (Stergašek et al., 2008; Wang et al., 2010).

\section{Conclusions}

The plume of the Lippendorf coal-fired power plant (CFPP), near Leipzig in Germany, was encountered several times on 21 and 22 August 2013. On 21 August the plume was captured at below planetary boundary layer top due to a temperature inversion layer. $\mathrm{Hg} / \mathrm{SO}_{2}, \mathrm{Hg} / \mathrm{CO}$, and $\mathrm{NO}_{x} / \mathrm{SO}_{2}$ ERs in the plume were determined as a slope of bivariate correlations of the species concentrations and as ratios of integrals over the individual plume crossings. The measured $\mathrm{Hg} / \mathrm{SO}_{2}$ and $\mathrm{Hg} / \mathrm{CO}$ ERs were, within the measurement uncertainties, consistent with the ERs calculated from annual emissions reported by the CFPP operator for 2013, while the $\mathrm{NO}_{x} / \mathrm{SO}_{2}$ ER was somewhat lower.

GOM fraction of total mercury emissions was estimated (a) using GOM measurements by $\mathrm{KCl}$ denuders, (b) from a difference between $\mathrm{Hg}$ measurements taken by Tekran instruments without and with a quartz wool trap, and (c) from a difference between $\mathrm{Hg}$ measurements take by a Tekran instrument without a quartz wool trap and GEM specific measurements taken by a Lumex instrument. Despite large uncertainties in all these estimates, we conclude that GOM emissions represent less than $25 \%$ of the total mercury emissions. This result is consistent with $20 \%$ found by Schütze et al. (2015) in stack gases of the Lippendorf CFPP in 2013 and findings by others (Edgerton et al., 2006; Stergašek et al., 2008; Wang et al., 2010; Deeds et al., 2013). It suggests that GOM fractions of $\sim 40 \%$ of CFPP mercury emissions in current emission inventories are overestimated. Although PBM was not measured by us, its inventoried fraction of $10 \%$ is, according to the references above, too high for CFPPs with FGD. 


\section{Data availability}

The data sets are available from the GMOS data portal (http: //sdi.iia.cnr.it/geoint/publicpage/GMOS/gmos_aircraft.zul; jsessionid=3B2706156E3CB087D2B3FD9A150B58E1).

Acknowledgements. Measurements were carried out as part of the European Tropospheric Mercury Experiment (ETMEP) within the Global Mercury Observation System project (GMOS; www.gmos.eu). GMOS is financially supported by the European Union within the seventh framework programme (FP-7, Project ENV.2010.4.1.3-2). Special thanks are due to Compagnia Generale Ripreseaeree (http://www.terraitaly.it/) in Parma, Italy, and the pilots, Oscar Gaibazzi and Dario Sassi, for carrying out the measurement flights.

The article processing charges for this open-access publication were covered by a Research

Centre of the Helmholtz Association.

Edited by: F. Sprovieri

Reviewed by: three anonymous referees

\section{References}

Ambrose, J. L., Lyman, S. N., Huang, J., Gustin, M. S., and Jaffe, D. A.: Fast time resolution oxidized mercury measurements during the Reno Atmospheric Mercury Intercomparison Experiment (RAMIX), Environ. Sci. Technol., 47, 7285-7294, 2013.

Ambrose, J. L., Gratz, L. E., Jaffe, D. A., Campos, T., Flocke, F. M., Knapp, D. J., Stechman, D. M., Stell, M., Weinheimer, A., Cantrell, C., and Mauldin, R. L.: Mercury emission ratios from coal-fired power plants in the southeastern US during NOMADSS, Environ. Sci. Technol., 49, 10389-10397, 2015.

Amos, H. M., Jacob, D. J., Holmes, C. D., Fisher, J. A., Wang, Q., Yantosca, R. M., Corbitt, E. S., Galarneau, E., Rutter, A. P., Gustin, M. S., Steffen, A., Schauer, J. J., Graydon, J. A., Louis, V. L. St., Talbot, R. W., Edgerton, E. S., Zhang, Y., and Sunderland, E. M.: Gas-particle partitioning of atmospheric $\mathrm{Hg}(\mathrm{II})$ and its effect on global mercury deposition, Atmos. Chem. Phys., 12, 591-603, doi:10.5194/acp-12-591-2012, 2012.

Bieser, J., DeSimone, F., Gencarelli, C., Geyer, B., Hedgecock, I. M., Matthias, V., Travnikov, O., and Weigelt, A.: A diagnostic evaluation of modelled mercury wet depositions in Europe using atmospheric speciated high resolution observations, Environ. Sci. Pollut. Res., 21, 9995-10012, doi:10.1007/s11356-0142863-2, 2014.

Cantrell, C. A.: Technical Note: Review of methods for linear leastsquares fitting of data and application to atmospheric chemistry problems, Atmos. Chem. Phys., 8, 5477-5487, doi:10.5194/acp8-5477-2008, 2008.

Chen, Y., Wang, R., Shen, H., Li, W., Chen, H., Huang, Y., Zhang, Y., Chen, Y., Su. S., Lin, N., Liu, J., Li, B., Wang, X., Coveney Jr., R. M., and Tao, S.: Global mercury emissions from combustion in light of international fuel trading, Environ. Sci. Technol., 48, 1727-1735, 2014.
Deeds, D.A., Banic, C.M., Lu, J., and Daggupaty, S.: Mercury speciation in a coal-fired power plant plume: An aircraft-based study of emissions from the 3640 MW Nanticoke Generating Station, Ontario, Canada, J. Geophys. Res., 118, 4919-4935, 2013.

Ebinghaus, R., Jennings, S. G., Schroeder, W. H., Berg, T., Donaghy, T., Guentzel, J., Kenny, C., Kock, H. H., Kvietkus, K., Landing, T., Mühleck, T., Munthe, J., Prestbo, E. M., Schneeberger, D., Slemr, F., Sommar, J., Urba, A., Wallschläger, D., and Xiao, Z.: International field intercomparison measurements of atmospheric mercury species at Mace Head, Ireland, Atmos. Environ., 33, 3063-3073, 1999.

Ebinghaus, R. and Slemr, F.: Aircraft measurements of atmospheric mercury over southern and eastern Germany, Atmos. Environ., 34, 895-903, doi:10.1016/S1352-2310(99)00347-7, 2000.

Edgerton, E. S., Hartsell, B. E., and Jansen, J. J.: Mercury speciation in coal-fired power plant plumes observed at three surface sites in the southeastern US, Environ. Sci. Technol., 40, 4563-4570, 2006.

EEA (European Environmental Agency): Revealing the Costs of Air Pollution from Industrial Facilities, Technical Report 15/2011, doi:10.2800/84800, Kopenhagen, 2011.

EPA (Environmental Protection Agency): Electric Generating Utility Mercury Speciation Profiles for the Clean Air Mercury Rule, EPA-454/R-11-010, Research Triangle Park, NC, USA, November 2011.

Gustin, M. S., Huang, J., Miller, M. B., Peterson, C., Jaffe, D. A., Ambrose, J., Finley, B. D., Lyman, S. N., Call, K., Talbot, R., Feddersen, D., Mao, H., and Lindberg, S. E.: Do we understand what the mercury speciation instruments are actually measuring? Results of RAMIX, Environ. Sci. Technol., 47, 7295-7306, 2013.

Gustin, M. S., Amos, H. M., Huang, J., Miller, M. B., and Heidecorn, K.: Measuring and modeling mercury in the atmosphere: a critical review, Atmos. Chem. Phys., 15, 5697-5713, doi:10.5194/acp-15-5697-2015, 2015.

Holmes, C. D., Jacob, D. J., Corbitt, E. S., Mao, J., Yang, X., Talbot, R., and Slemr, F.: Global atmospheric model for mercury including oxidation by bromine atoms, Atmos. Chem. Phys., 10, 12037-12057, doi:10.5194/acp-10-12037-2010, 2010.

Huang, J. and Gustin, M. S.: Uncertainties of gaseous oxidized mercury measurements using $\mathrm{KCl}$-coated denuders, cation-exchange membranes, and nylon membranes: Humidity influences, Environ. Sci. Technol., 49, 6102-6108, doi:10.1021/acs.est.5b00098, 2015.

Jaffe, D. A., Lyman, S., Amos, H. M., Gustin, M. S., Huang, J., Selin, N. E., Levin, L., ter Schure, A., Mason, R. P., Talbot, R., Rutter, A., Finley, B., Laeglé, L., Shah, V., McClure, C., Ambrose, J., Gratz, L., Lindberg, S., Weiss-Penzias, P., Sheu, G.-R., Feddersen, D., Horvat, M., Dastoor, A., Hynes, A. J., Mao, H., Jonke, J. E., Slemr, F., Fisher, J. A., Ebinghaus, R., Zhang, Y., and Edwards, G.: Progress on understanding atmospheric mercury hampered by uncertain measurements, Environ. Sci. Technol., 48, 7204-7206, doi:10.1021/es5026432, 2014.

Kaiser, R. and Gottschalk, G.: Elementare Tests zur Beurteilung von Meßdaten, Hochschultaschenbücher, Band 774, Bibliographisches Institut, Mannheim, 1972.

Kos, G., Ryzhkov, A., Dastoor, A., Narayan, J., Steffen, A., Ariya, P. A., and Zhang, L.: Evaluation of discrepancy between measured 
and modelled oxidized mercury species, Atmos. Chem. Phys., 13, 4839-4863, doi:10.5194/acp-13-4839-2013, 2013.

Lai, S. C., Baker, A. K., Schuck, T. J., Slemr, F., Brenninkmeijer, C. A. M., van Velthoven, P., Oram, D. E., Zahn, A., and Ziereis, H.: Characterization and source regions of 51 high-CO events observed during the Civil Aircraft for the Regular Investigation of the atmosphere Based on the Instrument Container (CARIBIC) flights between South China and the Philippines, 2005-2008, J. Geophys. Res., 116, D20308, doi:10.1029/2011JD016375, 2011.

Landis, M. S., Ryan, J. V., ter Schure, A. F. H., and Laudal, D.: Behavior of mercury emissions from a commercial coal-fired power plant: The relationship between stack speciation and near-field plume measurements, Environ Sci. Technol., 48, 13540-13548, 2014.

Lindberg, S., Bullock, R., Ebinghaus, R., Engstrom, D., Feng, X., Fitzgerald, W., Pirrone, N., Prestbo, E., and Seigneur, C.: A synthesis of progress and uncertainties in attributing the sources of mercury in deposition, AMBIO, 36, 19-33, 2007.

Lohman, K., Seigneur, C., Edgerton, E., and Janssen, J.: Modeling mercury in power plant plumes, Environ. Sci. Technol, 40, 38483854, 2006.

Lyman, S. N., Jaffe, D. A., and Gustin, M. S.: Release of mercury halides from $\mathrm{KCl}$ denuders in the presence of ozone, Atmos. Chem. Phys., 10, 8197-8204, doi:10.5194/acp-10-81972010, 2010.

Lyman, S. N. and Jaffe, D. A.: Formation and fate of oxidized mercury in the upper troposphere and lower stratosphere, Nat. Geosci., 5, 114-117, doi:10.1038/NGEO1353, 2012.

Mason, R. P.: Mercury emissions from natural processes and their importance in the global mercury cycle, in: Mercury Fate and Transport in the Global Atmosphere, edited by: Pirrone, N. and Mason, R., Springer Dordrecht, 173-191, 2009.

Mayer, J., Hopf, S., van Dijen, F., and Baldini, A.: Measurement of low mercury concentrations in flue gases of combustion plants, VGB PowerTech Journal, 3/2014, 64-68, 2014.

Mergler, D., Anderson, H. A., Chan, L. H. N., Mahaffey, K. R., Murray, M., Sakamoto, M., and Stern, A. H.: Methylmercury exposure and health effects in humans: A worldwide concern, Ambio, 36, 3-11, 2007.

Pacyna, E. G., Pacyna, J. M., Steenhuisen, F., and Wilson, S.: Global anthropogenic mercury emission inventory for 2000, Atmos. Environ., 40, 4048-4063, 2006.

Pirrone, N., Cinnirella, S., Feng, X., Finkelman, R. B., Friedli, H. R., Leaner, J., Mason, R., Mukherjee, A. B., Stracher, G. B., Streets, D. G., and Telmer, K.: Global mercury emissions to the atmosphere from anthropogenic and natural sources, Atmos. Chem. Phys., 10, 5951-5964, doi:10.5194/acp-10-59512010, 2010.

Preiss, P., Roos, J., and Friedrich, R.: Assessment of Health Impacts of Coal Fired Power Stations in Germany, report by the Institute for Energy Economics and Rational Use of Energy (IER), University of Stuttgart, 29 March 2013.

Radke, L. F., Friedli, H. R., and Heikes, B. G.: Atmospheric mercury over the NE Pacific during spring 2002: Gradients, residence time, upper troposphere lower stratosphere loss, and long-range transport, J. Geophys. Res., 11, 1-17, doi:10.1029/2005JD005828, 2007.

Rösler, H.J., Beuge, P., Schrön, W., Hahne, K., and Bräutigam, S.: Die anorganischen Komponenten der Braunkohlen und ihre Be- deutung für die Braunkohlenerkundung, Freiburger Forschungshefte, C331, 53-70, 1977.

Rutter, A. P. and Schauer, J. J.: The effect of temperature on the gasparticle partitioning of reactive mercury in atmospheric aerosols, Atmos. Environ., 41, 8647-8657, 2007.

Scheele, M. P., Siegmund, P. C., and van Velthoven, P. F. J.: Sensitivity of trajectories to data resolution and its dependence on the starting point: In or outside a tropopause fold, Meteorol. Appl., 3, 267-273, doi:10.1002/met.5060030308, 1996.

Scheuhammer, A. M., Meyer, M. W., Sandheinrich, M. B., and Murray, M. W.: Effects of environmental methylmercury on the health of wild birds, mammals, and fish, Ambio, 36, 12-18, 2007.

Schofield, K.: Fuel-mercury combustion emissions: An important heterogeneous mechanism and an overall review of its implications, Environ. Sci. Technol., 42, 9014-9030, doi:10.1021/es801440g, 2008.

Schütze, J., Kunth, D., Weissbach S., and Koeser, H.: Mercury vapor pressure of flue gas desulfurization scrubber suspensions: Effects of pH level, gypsum, and iron, Environ. Sci. Technol., 46, 30083012, doi:10.1021/es203605h, 2012.

Schütze, J.: Quecksilberabscheidung in der nassen Rauchgasentschwefelung von Kohlekraftwerken, Beiträge zum Umweltschutz, Band 6/2013, Shaker Verlag, Aachen, 2013.

Schütze, J., Schilling, U., Hilbert, L., Strauß, J. H., and Hörtinger, T.: Quecksilberabscheidung am Beispiel des Kraftwerks Lippendorf, VGB Power Tech, 81-87, 2015.

Selin, N. E.: Global biogeochemical cycling of mercury: A review, Annu. Rev. Environ. Resour., 34, 43-63, doi:10.1146/annurev.environ.051308.084314, 2009.

Sholupov, S., Pogarev, S., Ryzhov, V., Mashyanov, N., and Stroganov, A.: Zeeman atomic absorption spectrometer RA$915+$ for direct determination of mercury in air and complex matrix samples, Fuel Process. Technol., 85, 473-485, 2004.

Slemr, F., Seiler, W., and Schuster, G.: Quecksilber in der Troposphere, Ber. Bunsenges. Phys. Chem., 82, 1142-1146, 1978.

Slemr, F., Seiler, W., Eberling, C., and Roggendorf, P.: The determination of total gaseous mercury in air at background levels, Anal. Chim. Ac., 110, 35-47, 1979.

Slemr, F., Schuster, G., and Seiler, W: Distribution, speciation, and budget of atmospheric mercury, J. Atmos. Chem., 3, 407-434, 1985.

Slemr, F., Ebinghaus, R., Brenninkmeijer, C. A. M., Hermann, M., Kock, H. H., Martinsson, B. G., Schuck, T., Sprung, D., van Velthoven, P., Zahn, A., and Ziereis, H.: Gaseous mercury distribution in the upper troposphere and lower stratosphere observed onboard the CARIBIC passenger aircraft, Atmos. Chem. Phys., 9, 1957-1969, doi:10.5194/acp-9-1957-2009, 2009.

Slemr, F., Weigelt, A., Ebinghaus, R., Brenninkmeijer, C., Baker, A., Schuck, T., Rauthe-Schöch, A., Riede, H., Leedham, E., Hermann, M., van Velthoven, P., Oram, D., O'Sullivan, D., Dyroff, C., Zahn, A., and Ziereis, H.: Mercury plumes in the global upper troposphere observed during flights with the CARIBIC observatory from May 2005 until June 2013, Atmosphere, 5, 342-369, doi:10.3390/atmos5020342, 2014.

Spencer, R. W. and Braswell, W. D.: How dry is the tropical free troposphere?? Implications for global warming theory, B. Am. Meteorol. Soc., 78, 1097-1106, 1996.

Stergašek, A., Horvat, M., Kotnik, J., Tratnik, J., Frkal, P., Kocman, D., Jaćimović, R., Fajon, V., Ponikvar, M., Hrastel, I., Lenart, J., 
Debeljak, B., and Čujež, M.: The role of flue gas desulphurisation in mercury speciation and distribution in a lignite burning power plant, Fuel, 87, 3504-3512, 2008.

Tatum Ernest, C., Donohue, D., Bauer, D., Ter Schure, A., and Hynes, A. J.: Programmable thermal dissociation of reactive gaseous mercury, a potential approach to chemical speciation: Results from a field study, Atmosphere, 5, 575-596, doi:10.3390/atmos5030575, 2014.

VGB: VGB Initiative " $\mathrm{Hg}^{\text {cap": }}$ Further reduction of mercury emissions from coal-fired power plants, Position paper, VBG, Essen, March 2016.

Wang, S. X., Zhang, L., Li, G. H., Wu, Y., Hao, J. M., Pirrone, N., Sprovieri, F., and Ancora, M. P.: Mercury emission and speciation of coal-fired power plants in China, Atmos. Chem. Phys., 10, 1183-1192, doi:10.5194/acp-10-1183-2010, 2010.

Weigelt, A., Temme, C., Bieber, E., Schwerin, A., Schuetze, M., Ebinghaus, R., and Kock, H. H.: Measurements of atmospheric mercury species at a German rural background site from 2009 to 2011 - methods and results, Environ. Chem., 10, 102-110, doi:10.1071/EN12107, 2013.

Weigelt, A., Ebinghaus, R., Pirrone, N., Bieser, J., Bödewadt, J., Esposito, G., Slemr, F., van Velthoven, P. F. J., Zahn, A., and Ziereis, H.: Tropospheric mercury vertical profiles between 500 and $10000 \mathrm{~m}$ in central Europe, Atmos. Chem. Phys., 16, 41354146, doi:10.5194/acp-16-4135-2016, 2016.

Weiss-Penzias, P., Amos, H. M., Selin, N. E., Gustin, M. S., Jaffe, D. A., Obrist, D., Sheu, G.-R., and Giang, A.: Corrigendum to "Use of a global model to understand speciated atmospheric mercury observations at five high-elevation sites" published in Atmos. Chem. Phys., 15, 1161-1173, 2015, Atmos. Chem. Phys., 15, 2225-2225, doi:10.5194/acp-15-2225-2015, 2015.
Wilson, S., Munthe, J., Sundseth, K., Kindbom, K., Maxson, P., Pacyna, J., and Steenhuisen, F.: Updating Historical Global Inventories of Anthropogenic Mercury Emissions to Air, Arctic Monitoring and Assessment Programme (AMAP) Technical Report No. 3., AMAP Secretariat, Oslo, Norway, 2010.

Wilson, S., Kindborn, K., Yaramenka, K., Steenhuisen, F., Telmer, K., and Munthe, J.: Global emission of mercury to the atmosphere, in AMAP/UNEP, Technical Background Report for the Global Mercury Assessment, Arctic Monitoring and Assessment Programme, Oslo, Norway/UNEP Chemicals Branch, Geneva, Switzerland, 2013.

Yudovich, Y. E. and Ketris, M. P.: Mercury in coal - a review: Part 1: Geochemistry, Int. J. Coal Geology, 62, 107-134, 2005.

Zhang, L., Blanchard, P., Gay, D. A., Prestbo, E. M., Risch, M. R., Johnson, D., Narayan, J., Zsolway, R., Holsen, T. M., Miller, E. K., Castro, M. S., Graydon, J. A., Louis, V. L. St., and Dalziel, J.: Estimation of speciated and total mercury dry deposition at monitoring locations in eastern and central North America, Atmos. Chem. Phys., 12, 4327-4340, doi:10.5194/acp-12-43272012, 2012a.

Zhang, Y., Jaeglé, L., van Donkelaar, A., Martin, R. V., Holmes, C. D., Amos, H. M., Wang, Q., Talbot, R., Artz, R., Brooks, S., Luke, W., Holsen, T. M., Felton, D., Miller, E. K., Perry, K. D., Schmeltz, D., Steffen, A., Tordon, R., Weiss-Penzias, P., and Zsolway, R.: Nested-grid simulation of mercury over North America, Atmos. Chem. Phys., 12, 6095-6111, doi:10.5194/acp12-6095-2012, $2012 b$. 